Afghanistan Teacher Education Project (TEP)

\title{
SITUATIONAL ANALYSIS
}

\section{Teacher Education and Professional Development in Afghanistan}

August 2004

\section{Afghanistan Research \& Evaluation Unit} (AREU)

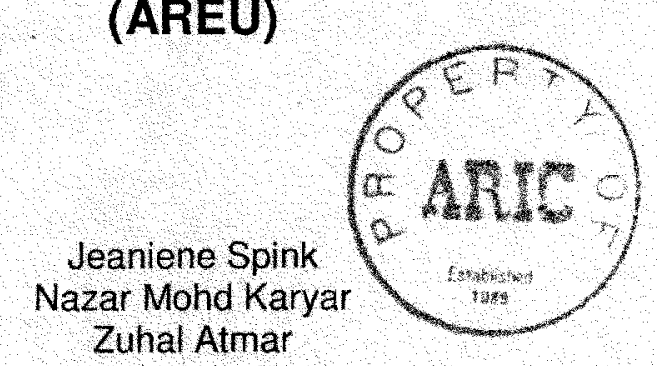

This working paper was produced in conjunction with

Creative Associates International, Inc. and supported through funding from the U.S. Agency for International Development (USAID) 


\section{TABLE OF CONTENTS}

A. BACKGROUND TO THE STUDY 4

Methodology 5

B. BACKGROUND - EDUCATION IN AFGHANISTAN 5

B.1 Ministry of Education and Ministry of Higher Education Structure 5

B.2 Coordination of Education Programmes 7

B.3 Student Schooling Structure and Schedules 77

B.4 Government Financial Planning for Teachers \& Teacher Training 8

B.4.1 Government Supported Teacher Salaries and Benefits 8

B.5 Statistics on Teachers 10

B.6 Formal and Non-Formal Teacher Education Programmes $\quad 14$

Analysis Section B $\quad 15$

C. TEACHER TRAINING PLANS AND ACTIVITIES 16

C.1 Government Support to Teacher Education 16

$\begin{array}{ll}\text { C.1.1 Teacher Training Colleges } & 17\end{array}$

C.1.2 In-service Regional Centres $\quad 21$

C. 1.3 Institutes of Higher Education/Universities 22

C.2 International Organisations Support to Teacher Training $\quad 24$

C.21 UNICEF/Teachers College, Columbia University $\quad 24$

C.2.2 TEP Rapid Teacher Training Programme 24

C.2.3 World Bank 25

C.2.4 ADB Rural Education Project $\quad 25$

C.2.5 Creative Associates APEP Accelerated Learning Programme 25

C.2.6 CARE COPE Project $\quad 25$

C.2.7 AKDN Rural Education Support Programme $\quad 26$

C.2.8 IRC Teacher Training Programme 26

C.2.9 BRAC Community-Based Schools 26

Analysis Section C $\quad 27$

D. LEARNING FROM EXPERIENCE $\quad 29$

D.1 Learning from Afghanistan 29

D.2 Learning from the Region $\quad 32$

D.2.1 Basic Competency Learning (BCL) Materials 32

D.2.2 Returning Afghan Teachers from the Region 33

Analysis Section D $\quad 34$

E. CONCLUSIONS AND RECOMMENDATIONS 35 


\section{Acronyms}

$\begin{array}{ll}\text { ADB } & \text { Asian Development Bank } \\ \text { AKDN } & \text { Aga Khan Development Network } \\ \text { APEP } & \text { Afghanistan Primary Education Programme } \\ \text { AREU } & \text { Afghanistan Research and Evaluation Unit } \\ \text { ATEP } & \text { Afghanistan Teacher Education Programme } \\ \text { BCL } & \text { Basic Competency Learning } \\ \text { BEFAR } & \text { :Basic Education for Afghan Refugees } \\ \text { BRAC } & \text { Bangladesh Rural Advancement Coordinator } \\ \text { CAII } & \text { Creative Associates International, Inc. } \\ \text { CARE } & \text { CARE International } \\ \text { CDC } & \text { Community Development Council } \\ \text { COPE } & \text { Community Organised Primary Education } \\ \text { DANIDA } & \text { Danish International Development Agency } \\ \text { DED } & \text { District Education Department } \\ \text { EMIS } & \text { Education Management Information System } \\ \text { EQUIP } & \text { Education Quality Improvement Programme } \\ \text { GoA } & \text { Government of Afghanistan } \\ \text { GTZ } & \text { German Technical Cooperation } \\ \text { IDP } & \text { Internally Displaced Person } \\ \text { IHE } & \text { Institute for Higher Education } \\ \text { INSET } & \text { In-service Training } \\ \text { IT } & \text { Information Technology } \\ \text { JICA } & \text { Japanese International Cooperation Agency } \\ \text { MOE } & \text { Ministry of Education } \\ \text { MoHE } & \text { Ministry of Higher Education } \\ \text { NDB } & \text { National Development Budget } \\ \text { NGO } & \text { Non-Government Organisation } \\ \text { PED } & \text { Provincial Education Department } \\ \text { PRC } & \text { Provincial Resource Centres } \\ \text { PRESET } & \text { Pre-Service Training } \\ \text { SC/US } & \text { Save the Children, US } \\ \text { STEP } & \text { Strengthening Teacher Education Programme } \\ \text { TCCU } & \text { Teachers College, Columbia University } \\ \text { TTD } & \text { Teacher Training Department (in the Ministry of Education) } \\ \text { TTA } & \text { Teacher Training Academy } \\ \text { UTC } & \text { United Nations Development Programme } \\ \text { UNDP } & \text { United Nations Educational, Scientific and Cultural Organisation } \\ \text { UNESCO } & \text { United Nations High Commissioner for Refugees } \\ \text { UNHCR } & \text { United Nations Children's Fund } \\ \text { UNO } & \text { Unency for International Development } \\ \text { UTited States } & \end{array}$




\section{Teacher Education and Professional Development in Afghanistan}

\section{A. BACKGROUND TO THE STUDY}

The Afghanistan Government has identified the professional development of teachers as a critical part of re-establishing the country's human capital and economy. In May 2002 a Comprehensive Needs Assessment' of the education sector was conducted together with the Afghan Interim Administration by a team of professionals from the World Bank, UNICEF, UNESCO and the Asian Development Bank (ADB). One of the key recommendations of the needs assessment report was to provide support for teacher professional development. More recently in 2004, the Ministry of Education (MoE) has released a number of education policy documents ${ }^{2}$ outlining their priorities. Teacher training is a key component of all education programmes for the Afghan Government. The most recent national Constitution of Afghanistan $(1382)^{3}$ stated that education was the right of all children and that the government would be responsible for providing basic education (that is up to grade 9) to all children of Afghanistan. While all of these documents highlight the importance and needs within the teacher training sector, activities and programmes remained relatively autonomous of each other until the beginning of 2004. The Afghanistan Teacher Education Programme (TEP), supported in part by Creative Associates International, Inc. (CAII), is the first concerted effort on behalf of all donors in the teacher training sector to develop a coordinated and integrated response to assist the $\mathrm{MoE}$ in achieving its goals for teacher development.

TEP is an initiative designed to support a coordinated response to teacher development in Afghanistan. Collaborating agencies include the Academic Council on Education, the MoE, the Ministry of Higher Education (MoHE), the United Nations Children's Fund (UNICEF), U.S. Agency for International Development (USAID), the World Bank, Danish International Development Agency (DANIDA), the Japan International Cooperation Agency (JICA) and CAII. The programme aims to: produce a long-term plan for teacher education in Afghanistan; identify and initiate immediate-term activities focusing on rapid, country-wide in-service teacher training programmes and setting up Teacher Resource Centres at a subdistrict level; and enable coordination among diverse inputs and delivery systems through a commonly agreed upon approach. To date, two strands of work have been agreed upon:

1) A country-wide in-service training programme covering all teachers presently in schools; and

2) An overall Teacher Education Programme (TEP) focusing on long-term teacher development.

\footnotetext{
'Afghanistan Interim Administration (AIA), Comprehensive Needs Assessment for the Education Sector in Afghanistan, Afghanistan, Kabul, May 2002.

${ }^{2}$ Ministry of Education, Educational Development Plan: 1381-1394, Kabul, Afghanistan, January 2004.

---, National Development Plan and Budget 1383-1385, Kabul, Afghanistan, February, 2004.

---, Education as a Catalyst for the Rebuilding of Afghanistan: Education Priorities and Project Profiles, Afghanistan, March 2004.

World Bank, Securing Afghanistan's Future: Technical Annex on Education, Afghanistan, March 2004.

${ }^{3}$ Government of Afghanistan, Constitution of Afghanistan 1382, Kabul, Afghanistan, 2004
} 
This situational analysis is a part of the TEP activity. It aims to provide a short overview of teachers and teacher development programmes in Afghanistan to date, which can then be incorporated into longer-term development objectives for teacher training. Given the time constraints of this study, it is not intended as a detailed research programme. However, its findings may highlight areas where further information may be required and additional research initiatives could be recommended to ensure future teacher training programmes are coordinated, targeted, realistic and meet the actual needs of teachers in Afghanistan.

\section{Methodology}

This study was; conducted within a limited time frame of three weeks during August 2004. This did not allow for field assessment studies. The findings of this study are primarily the results of personal interviews in Kabul with $\mathrm{MoE}$ staff, NGOs and organisations supporting teacher training in Afghanistan. The study also incorporates the results of a number of evaluations and project documents. It outlines the activities of the $\mathrm{MoE}$, the $\mathrm{MoHE}$, organisations supporting teacher training and their plans for the future. Some important experiences of developing and implementing teacher-training programmes both in Afghanistan and in the immediate region have been highlighted.

The findings of the study have uncovered some areas that may deserve further investigation and research. Teacher training systems at the provincial level is an area where there was limited information. Also, as a part of this study it was hoped that a map of exactly where organisations are working could be made possible, however, time limitations prevented this. Such a map would show where there was a very high level of activity for teacher training and where gaps remained. A more qualitative study of teacher competencies and student learning achievements was also not possible within the time frame available.

The collection of student and teacher numbers for the institutes of higher education was not possible. At the central level, the MoHE only had information on the total number of students and teachers, which included those teachers and students in medical school, engineering and polytechnics. Only through personal visits to each of the sites in the provinces would it be possible to collect a full set of figures of students studying toward a degree related to education. It is acknowledged that the information collected at the central level may not be accurate when checked against actual figures from the provinces.

It was apparent during this study that a critical analysis of systems, programmes and individual capacities was a new concept. To develop an in-depth understanding of the actual issues at hand required many different interviews with different people - there remains a culture of not presenting problems, or issues, for fear of them being used in a detrimental way. A culture of self-evaluation in Afghanistan still needs to be developed which would then make possible the development of a meaningful monitoring and evaluation system and process of continual research and analysis.

\section{B. BACKGROUND - EDUCATION IN AFGHANISTAN}

\section{B.1 Ministry of Education and Ministry of Higher Education Structure}

In Afghanistan there are two ministries responsible for training teachers. These are the Ministry of Education (MoE) and Ministry of Higher Education (MoHE). The MoHE is responsible for the pedagogical institutes, the Institutes of Higher Education (IHEs) and the universities, all of which offer four-year degrees. At present, the MoHE is going through a transitional period and the various education facilities and institutes are still being defined by level of academic qualification and status. 
The MoE in Kabul is responsible for policy direction for education up to grade 12 . The MoE has a greater resource base than the MoHE, in terms of financial, human and technical resources. Within the MoE there are a number of departments. The Teacher Training Department (TTD) is responsible for national teacher training policies and programmes. They also manage the Teacher Training Colleges (TTCs) in the provinces. The TTD is also responsible for academic guidance to these colleges. There are plans to establish an Academy of Teacher Training as a part of the TTD, which will be responsible for a countrywide programme for in-service teacher training and support, which will bring teacher development programmes down to the district and school level, rather than centred in the primarily urban based TTCs. TTCs offer a two-year teacher training diploma for grade 12 graduates as well as a five-year diploma in teacher training for grade 9 graduates.

Unlike the MoHE, the MoE has a presence in each of the 34 provinces of Afghanistan. These are the Provincial Education Departments (PEDs) and are responsible for all budgeting and administration of schools and teachers in the province. The PEDs are supported by District Education Departments (DEDs) who have a presence in every district of the country although most DEDs do not have their own office and are often based in an annex of an existing school There is no regional administrative structure in Afghanistan. Each PED reports directly to the central MoE. All finances for the TTCs and DEDs are managed by the PED. On a quarterly basis a budget is allocated to the PEDs after the approval of the Governor of the province, the $\mathrm{MoE}$ and the Ministry of Finance. In each province there is a representative of the MoF, called a revenue collector, who is responsible for issuing all payments to all departments, including the PED.

In each PED there are two deputies, one administrative and one academic. Each of the deputies has a number of heads of departments reporting to them. These include a planning department, an inspection department and an employment department. In addition there is also a General Director for Teacher Training. This person is appointed by the TTD in Kabul and is the key link between the MoE and the TTCs. They are responsible for applying the policy of the TTD, ensuring all decrees and central government decisions are adhered to and enforcing all laws outlined by the MoE in relation to teacher training at the provincial level. ${ }^{4}$ All TTCs should report directly to the TTD in Kabul, however, because all finances are allocated through the PED, there remains a strong reporting linkage between the TTC and the PED.

\section{Figure 1: Teacher Training Structures of the MoE and MoHE}

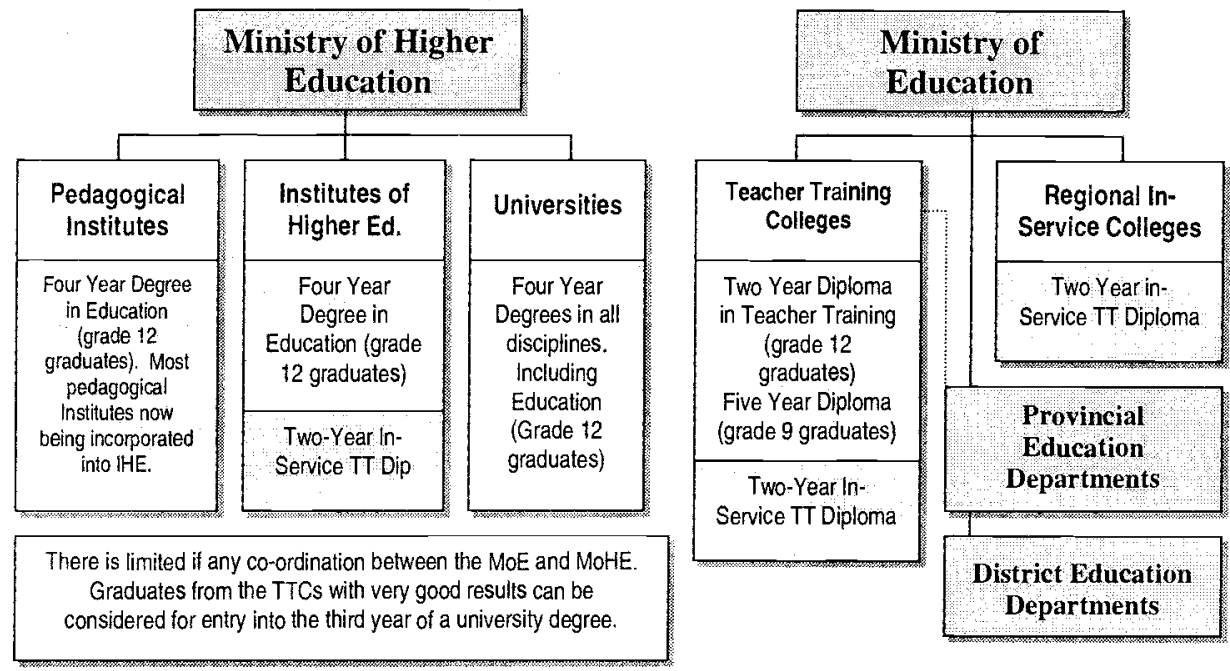

${ }^{4} \mathrm{MoE}$, Regulations of Duties of Teacher Training General Directorate, Kabul, Afghanistan, 2001. 


\section{B.2 Coordination of Education Programmes}

In 2002-2003 the education sector was largely coordinated through the Education Programme Secretariat. This secretariat reported directly to the Minister of Education and included a small team of international and national senior education professionals who organised regular coordination meetings around specific topics in the education sector. They were also responsible for the coordination of development funds as a part of the National Development Budget. The secretariat is no longer functioning, however, a grants management unit has since been established, which is also based in the $\mathrm{MoE}$, and which assists in the coordination of development funds to the ministry.

The arrival of the new head of the TTD has significantly contributed to a more effective coordination of teacher training activities. There is now a move on behalf of the $\mathrm{MoE}$ to understand more clearly the work of donors, UN and NGO groups. The ministry is now looking outside its own staff to learn from other programmes and to seek the support of other organisations that can assist with the ambitious task of a national teacher training programme.

In 2003 the $\mathrm{MoE}$, together with a group of donor organisations, such as CAII and UNICEF, conducted a three-day workshop to plan a response to teacher development in Afghanistan. This workshop, which was attended by a wide range of professionals and organisations supporting teacher training, identified as one of the major priorities a more coordinated response to teacher training in Afghanistan. Given this recommendation key education donor organisations decided to form a committee called the Teacher Education Programme (TEP). This group would work in close collaboration with the TTD to identify the key needs in teacher development and ensure a coordinated donor response to those needs. TEP has been working well until now and there is currently a move towards effective integrated programming in this sector.

\section{B.3 Student Schooling Structure and Schedules}

As a result of the most recently approved Constitution of Afghanistan (1382), education is compulsory for all children up to grade nine. Children start their first year of schooling at the age of seven. The Constitution also states that the government will provide education free of charge up to university level.

There are three levels of education: primary education (grade 1-6); junior secondary (grade 79); and upper secondary (grade 10-12). All diploma degrees are referred to as grade 13 and 14 A school year consists of two semesters. Depending on where the school is in Afghanistan (hot or cold area), the school year will begin at different times. In the "cold areas," such as in Kabul and most parts of the north of the country, the school year begins with the start of the Islamic New Year on March $21^{\text {st }}$ (or the first working day after this). In the "hot areas" such as the southern and southeastern provinces, the school year begins in September. The school year is typically nine months, with a two and a half month break at the end of each academic year. This break in the school year is when rapid in-service teacher training programmes have previously been conducted.

Most school days are for three to three and half hours. In the rural areas of Afghanistan most teachers teach for half the day and work in alternative jobs for the remainder of the day. For the urban areas, school facilities are often over crowded and schools function on a shift system. Some schools in Kabul have up to four shifts a day. This shift system is also sometimes used in other schools to provide segregated learning opportunities for girls and boys.

Schooling is not always segregated in Afghanistan. Depending on the location of the school, students may continue to attend co-educational classes until grade 12 . In other areas, the community is not willing to allow girls to go to class in a school that ever has boys at the 
school, even in a different shift. In areas such as this families will not allow their girls to go to school unless they have a female teacher that is known and trusted by the community. In many parts of the country, children attend co-educational classes until the end of primary school and then they are segregated once they move into junior secondary or upper secondary classes. Most TTCs, pedagogical institutes and universities have all classes with male and female students. Only boarding campuses are segregated.

There are three different career paths for students: religious studies, academic studies or vocational training. Most students have to decide which path to take once they graduate from grade 9. Only :students who decide to follow an academic path have the opportunity to graduate and be considered for either a TTC or an institute of higher education.

\section{B.4 Government Financial Planning for Teachers \& Teacher Training}

The proposed National Development Budget (NDB) ${ }^{5}$ for $1383(2004 / 2005)$ still emphasises inputs over quality $-67 \%$ of the total proposed education budget of US $\$ 453.84$ million is allocated to education infrastructure and equipment, with $10.5 \%$ for curriculum and teacher development. Within this $10.5 \%$, however, very little money is reserved for teacher training or the development of teacher materials. Most funds are reserved for the construction of teacher training facilities.

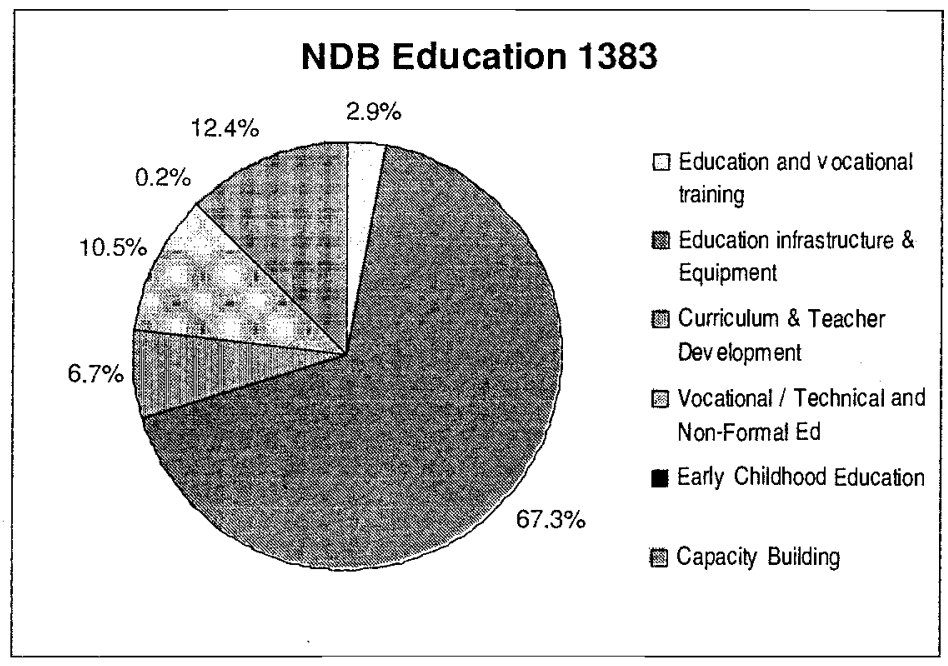

In 2003 funds spent outside the NDB, that is government-supported funds, were US $\$ 49.37$ million. Expenditure reporting of the MoE remains weak. There is very limited knowledge on behalf of the departments of what money has been allocated, what has been spent and what funds are still available. ${ }^{6}$

\section{B.4.1 Government Supported Teacher Salaries and Benefits}

In 2004 the Minister of Education approved a standard set of teacher salaries. This staggered salary scale is based on a basic salary and then increases depending on the number of years served as a teacher and the teacher's qualifications. In March 2004 the Minister of Education approved a significant increase in teachers' base salaries to bring them in line with other civil servant staff. Teachers are now paid a total salary that is comparable to all other civil servant

\footnotetext{
${ }^{5}$ Government of Afghanistan, Submission for the SY 1383-1385, National Development Budget, Ministry of Education, Ministry of Higher Education, Ministry of Social Affairs and Labour, 2004

${ }^{6}$ The NDB provides a list of recommendations of what needs to be done to improve the financial monitoring system of the MoE.
} 
staff of the government of Afghanistan. It is not clear, however, whether this change in salary levels is being implemented at the field and school level.

In accordance with the new approved system, each teacher works through a graded scale of 1 to 10. All new teachers who enter the teaching profession for the first time start at level 10 . After three years this staff person will be promoted to the next level, e.g., level 9. The base salary per month for a teacher starting on level 10 is 69 Afghanis. An additional amount is added to this base salary depending on the qualifications of the teacher. If the teacher has , completed grade 12, but has no further education, 900 additional Afghanis is paid.

Complimentary to the base salary a standard sum of 1,600 Afghanis is paid to each teacher for food. The teacher must be registered as attending class to receive this amount. The figure is calculated at the rate of 60 Afghanis per day from Saturday to Wednesday and then 40 Afghanis from Thursday to Friday each week. A transportation benefit of 120 Afghanis is also paid to each teacher. If a teacher is included in a teacher-training programme where they cannot attend class, the food and transport benefit will not be paid. A final benefit to the teacher is a bonus per month depending on their qualifications. If a teacher has completed grade 12 they will receive a bonus of 8 Afghanis per month. If they have completed a bachelor degree they will receive a monthly bonus of 20 Afghanis.

Figure 2: Summary of Teacher Salary Scales (in Afghanis)

\begin{tabular}{|c|c|c|c|c|c|c|c|c|}
\hline mank & $\begin{array}{l}\text { Years } 10 \\
\text { reach } \\
\text { this level }\end{array}$ & $\begin{array}{l}\text { pase } \\
\text { salay }\end{array}$ & $\begin{array}{l}\text { Below } \\
\text { grade } 12 \\
(+800)\end{array}$ & $\begin{array}{l}\text { Grade } 12 \\
(+900)\end{array}$ & $\begin{array}{l}\text { Grade } 13 \\
(+1000)\end{array}$ & $\begin{array}{c}\text { Grade } 14) \\
(+1100)\end{array}$ & Dachelor & $\begin{array}{l}\text { Masters } \\
\text { or higher } \\
(41500)\end{array}$ \\
\hline $75 \%$ up & $>4$ & 271 & 2033 & 2208 & 2383 & 2558 & 2908 & 3258 \\
\hline $50 \%$ up & $>3$ & 181 & 1743 & 1893 & 2043 & 2193 & 2493 & 2793 \\
\hline $25 \%$ up & $>2$ & 90 & 1452 & 1577 & 1702 & 1827 & 2077 & 2327 \\
\hline $15 \%$ up & $>1$ & 54 & 1336 & 1451 & 1566 & 1681 & 1911 & 2141 \\
\hline Higher & $>4$ & 363 & 1162 & 1262 & 1362 & 1462 & 1662 & 1862 \\
\hline Higher $^{*}$ & $>3$ & 293 & 1093 & 1193 & 1293 & 1393 & 1593 & 1793 \\
\hline 1 & $>3$ & 224 & 1024 & 1124 & 1224 & 1324 & 1524 & 1724 \\
\hline 2 & $>3$ & 189 & 989 & 1089 & 1189 & 1289 & 1489 & 1689 \\
\hline 3 & $>3$ & 163 & 963 & 1063 & 1163 & 1263 & 1463 & 1663 \\
\hline 4 & $>3$ & 134 & 934 & 1034 & 1134 & 1234 & 1434 & 1634 \\
\hline 5 & $>3$ & 120 & 920 & 1020 & 1120 & 1220 & 1420 & 1620 \\
\hline 6 & $>3$ & 106 & 906 & 1006 & 1106 & 1206 & 1406 & 1606 \\
\hline 7 & $>3$ & 98 & 898 & 998 & 1098 & 1198 & 1398 & 1598 \\
\hline 8 & $>3$ & 87 & 887 & 987 & 1087 & 1187 & 1387 & 1587 \\
\hline 9 & $>3$ & 79 & 879 & 979 & 1079 & 1179 & 1379 & 1579 \\
\hline 10 & & 69 & 869 & 969 & 1069 & 1169 & 1369 & 1569 \\
\hline \multicolumn{3}{|c|}{ Additional bonus } & 0 & 8 & 12 & 15 & 20 & 25 \\
\hline \multicolumn{3}{|c|}{ Food Allowance } & \multicolumn{6}{|c|}{ 1,600/month (Sat-Wed 60 afgh/day Thus-Fri 40 afgh/day) } \\
\hline \multicolumn{3}{|c|}{ Transportation Costs } & \multicolumn{6}{|c|}{$120 /$ month (5 afgh per day 6 days per week) } \\
\hline
\end{tabular}

* The "higher" category is for those staff working in the central or provincial MoE offices.

(Source: Ministry of Education Planning Department 2004)

An understanding of the additional benefits to teachers assists all organisations that pay a per diem for training. At present there is no standard set of per diems for teacher training, with some organisations paying no per diem and other organisations paying a very high per diem. Benefits paid to teachers totals approximately US $\$ 35$ per month, which is about US $\$ 1.40$ per day, based on a six day working week.

A teacher who has completed a TTC course and who has worked as a teacher for six years will receive 1,187 (base salary) plus 15 (bonus) Afghanis per month. In addition they will receive 120 (transport) plus 1,600 (food) Afghanis every month. The total salary for this teacher will be 2,922 Afghanis (approx US\$68) per month. 
At present only the pre-service and long-term in-service teacher training courses provided by the $\mathrm{MoE}$ are recognised as affecting salary scales. All in-service teacher training programmes run by NGOs and UN organisations, although accredited by the MoE, have no effect on a teacher's level of salary.

The World Bank concludes through a comparison of some 50 developing countries that a reasonable target for teacher pay is a multiple of 3.3 times per capita GDP. ${ }^{7}$ This is considered to be the average teacher salary in better performing countries. Currently Afghanistan's teachers are paid on average 2.7 times per capita GDP. The objective is to raise this level to 3.1 times per capita GDP by 2015. The World Bank estimates that the figure for per capita GDP in Afghanistan should be US $\$ 493$ by $2015^{8}$

A number of organisations supporting educational programmes in Afghanistan are paying a wide range of salaries/stipends/incentives to teachers. Other organisations are only supporting community in-kind support to teachers and do not pay a financial reward to them. It was not within the scope of this study to understand exactly the amount each organisation was paying each teacher, or whether teachers were in fact receiving their salaries from the MoE, however, the above guide may assist in creating a more standardised payment system.

\section{B.5 Statistics on Teachers}

A detailed understanding of the numbers of teachers, student/teacher ratios, teacher qualifications, teacher capacities and student learning achievements is not accurately known in Afghanistan. In 2002 UNICEF conducted a national Rapid Assessment of Learning Spaces. This assessment showed a total number of approximately 70,000 teachers and approximately 3.2 million students: an average of $46: 1$ student/teacher ratio. At that time to achieve a ratio of 30:1 an additional 35-40,000 teachers were required. In 2003 UNICEF conducted a Multiple Indicator Cluster Survey, which collected detailed qualitative data in a select number of villages across the country. This presented an understanding of the issues at hand with regard to education, and figures of teachers and students could be extrapolated from the villages selected as a part of the survey. However, at present there remains no accurate statistical data on teachers for all of Afghanistan.

A number of documents have cited various numbers of teachers. In one document by the $\mathrm{MoE}$ two different figures are recorded for 2003: $102,000^{9}$ and $85,000 .{ }^{10}$ The National Development Plan gives a figure of $80,811 .^{11}$ The Department of Teacher Training quotes a figure of 105,525 teachers for the whole country. The World Bank records a total of 106,450 teachers for 2003. ${ }^{12}$ A provincial breakdown of teachers also will not be accurate, however, Kabul has by the far the highest number of teachers employed, with provinces in the south and southeast having the lowest.

Despite this confusion of figures, the MoE provides a detailed list of data broken down by primary, junior secondary and senior secondary. The data include: numbers of teachers by gender; number of students by gender; their location; and the number of schools. A full outline of these data is available in Annex A. A summary of the data is shown below.

\footnotetext{
${ }^{7}$ More details of this study can be found in the World Bank document, Bruns, Barbara, Alain Mingat and Ramahatra Rakotomalala. 2003. Achieving Universal Primary Education by 2015: A Chance for Every Child. Washington DC: World Bank.

${ }^{8}$ World Bank, Securing Afghanistan's Future, 2004.

${ }^{9} \mathrm{MoE}$, Education as a Catalyst, p. 6, 2004

${ }^{10}$ ibid, p. 27.

${ }^{11}$ MoE, National Development Plan, p.5 2004.

${ }^{12}$ World Bank, Security Afghanistan's Future, 2004.
} 
Figure 3: Summary of Teachers and Students by School Level

\begin{tabular}{|c|c|c|c|c|c|}
\hline No & School Level & $\begin{array}{c}\text { No of } \\
\text { Students }\end{array}$ & $\begin{array}{c}\text { No of } \\
\text { Teachers }\end{array}$ & No of Schools & $\begin{array}{c}\text { Student } \\
\text { Teacher Ratio }\end{array}$ \\
\hline 1 & Primary & $3,765,415$ & 52,948 & 5,257 & 71 \\
\hline 2 & Junior Secondary & 290,301 & 22,411 & 1,143 & 13 \\
\hline 3 & Upper Secondary & 113,690 & 25,336 & 938 & 4 \\
\hline & TOTAL & $4,169,406$ & 100,695 & 7,338 & 41 \\
\hline
\end{tabular}

(Source: Ministry of Education, Planning Department, 2004)

From the data it is possible to highlight a number of points. First, the student teacher ratio in primary education is by far the highest, at approximately 71 students per teacher. This ratio falls dramatically once the students graduate to junior secondary and upper secondary school. Provincial student to teacher ratios vary widely. This is illustrated by the below graphs for primary, junior secondary and upper secondary schools:

\section{Figure 4: Student to Teacher Ratios for Primary Schools by Province}

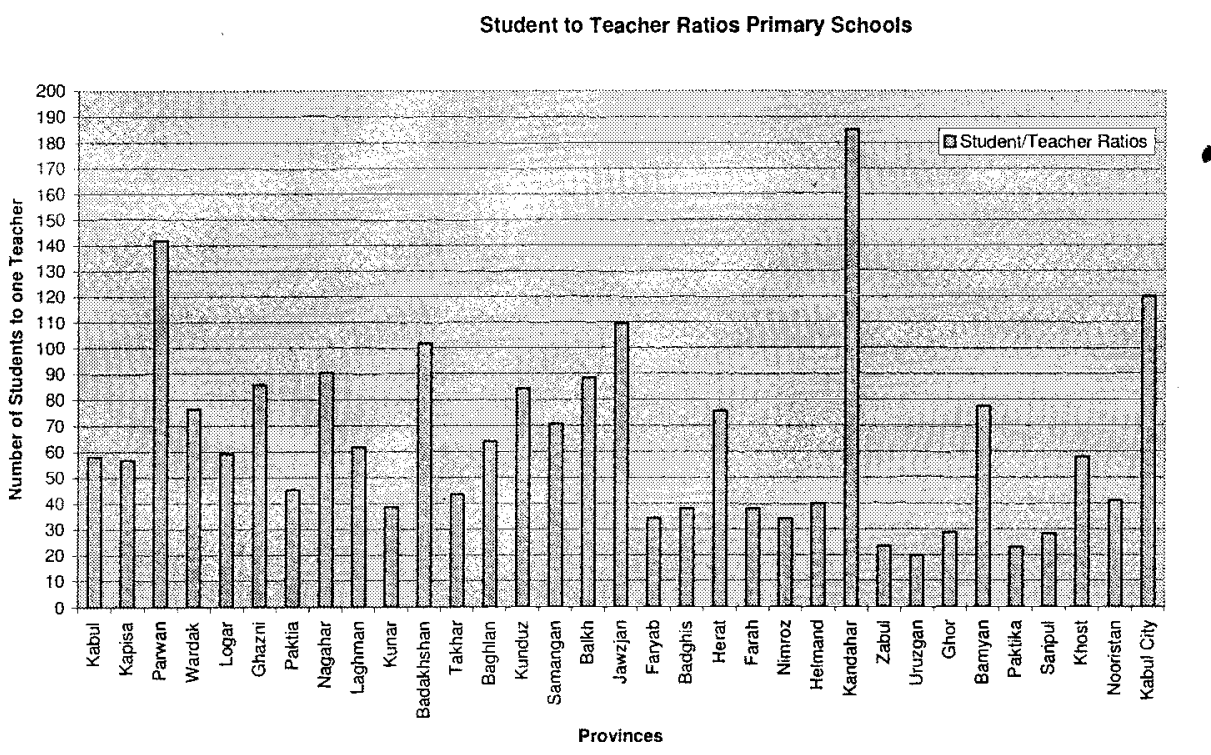

For primary schools the highest student to teacher ratio is in Kandahar (185:1), followed by Parwan (142:1), then Kabul City (120:1), Jawzjan (110:1) and Badakhshan (102:1). Kandahar also has the greatest shortage of female teachers. It is possible to get a basic picture of areas that may need additional female teachers when comparing male to female students in primary schools, shown in the next figure. Kabul City has more female than male students. 
Figure 5: Comparison of Male to Female Students in Primary School by Province

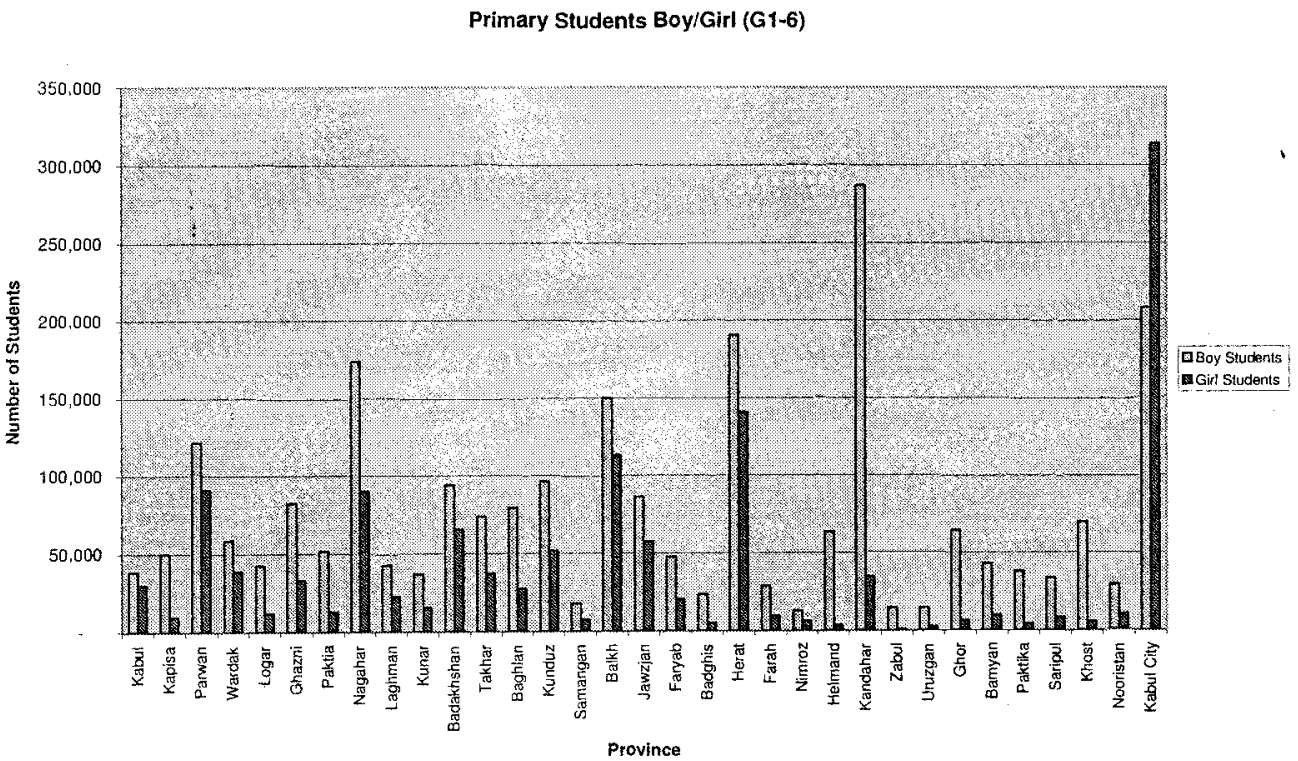

In junior secondary schools, the student to teacher ratio averages around 13 students to one teacher. However, as shown below, some provinces still have a shortage of junior secondary school teachers, such as Nooristan (79:1) and Khost (68:1). Kabul City has a ratio of less than 20 students to one teacher.

Figure 6: Student to Teacher Ratios for Junior Secondary Schools by Province

Student Teacher Ratios Junior Secondary

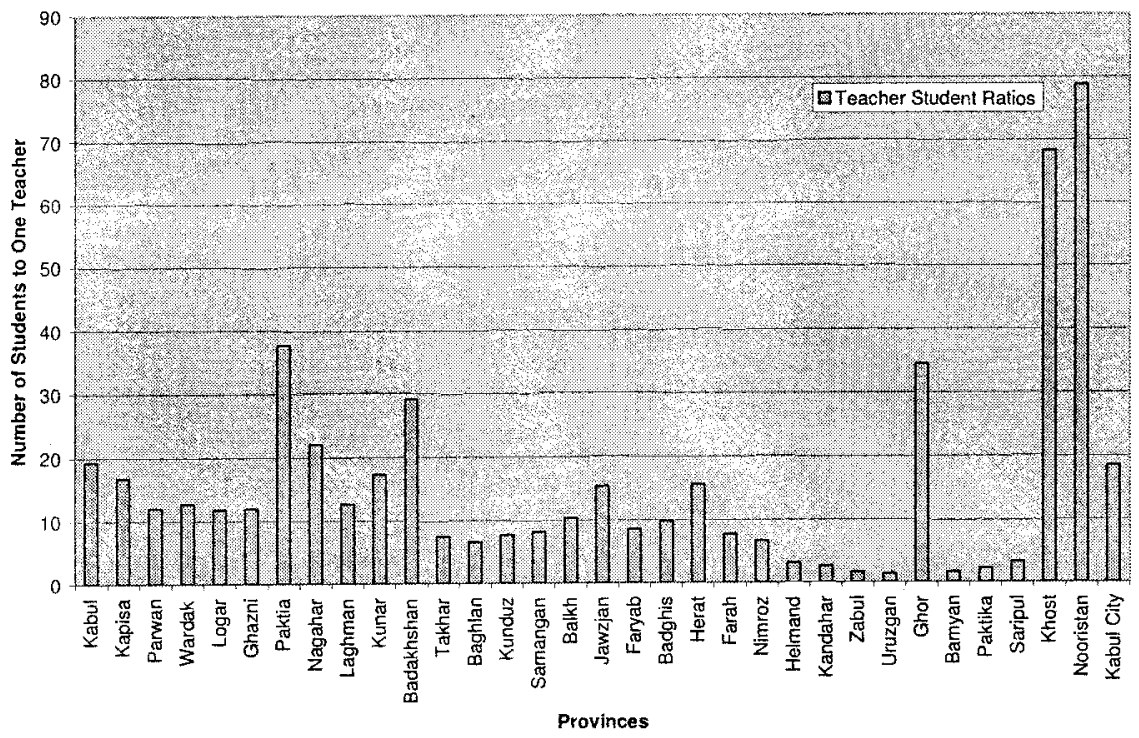

For upper secondary schools the ratios are different again. The average ratio is four students to one teacher. This varies depending on the location. Again, Nooristan has a high student to 
teacher ratio of almost 40 students to a teacher. Kabul City has a ratio of less than 10 students to one teacher.

Figure 7: Student to Teacher Ratio Upper Secondary Schools by Province

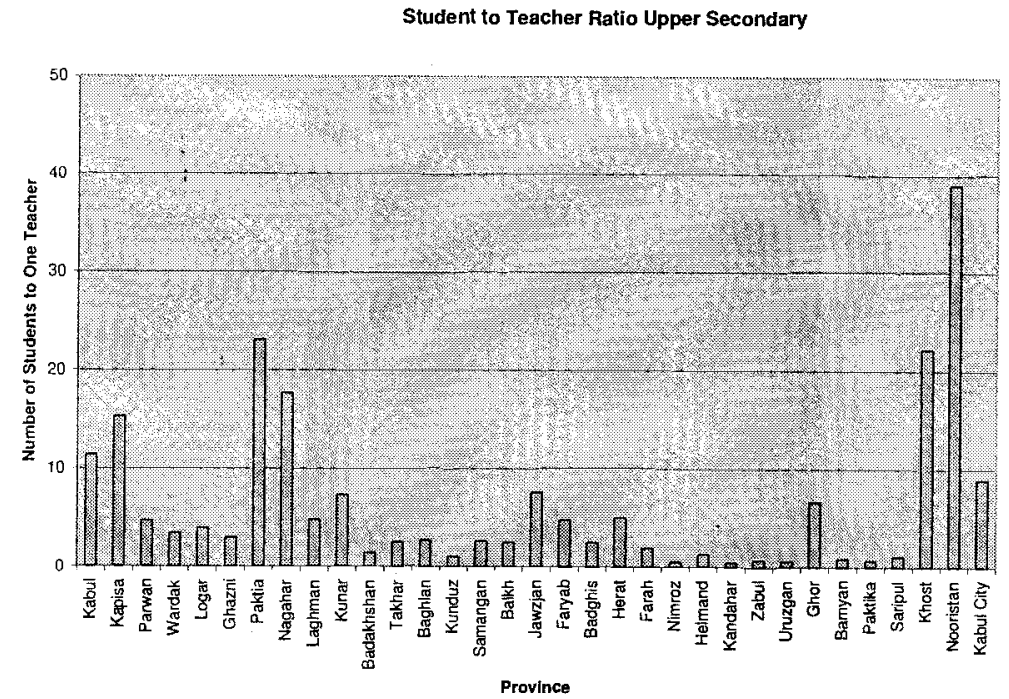

For all levels of education the average student to teacher ratio is 41 to one. To achieve a ratio of 30 students to one teacher an additional 38,000 teachers are required, all of whom will be needed in primary schools. However, the MoE figures indicate that the total additional number of teachers cannot be seen as the only solution to the shortage of teachers, and the allocation of these teachers also needs to be considered.

There is commonly a concern in Afghanistan of a severe lack of female teachers. This is not the case in Kabul City, which can be seen in the below graph to have substantially more female teachers at the primary school level. There are, however, significantly fewer female teachers than male teachers in all other parts of the country. Provinces such as Kunduz, Badghis, Helmand, Zabul, Ghor, Khost and Nooristan are particularly affected.

Figure 8: Comparison of Male to Female Primarv School Teachers bv Province Male to Female Teachers for Primary Schools by Province

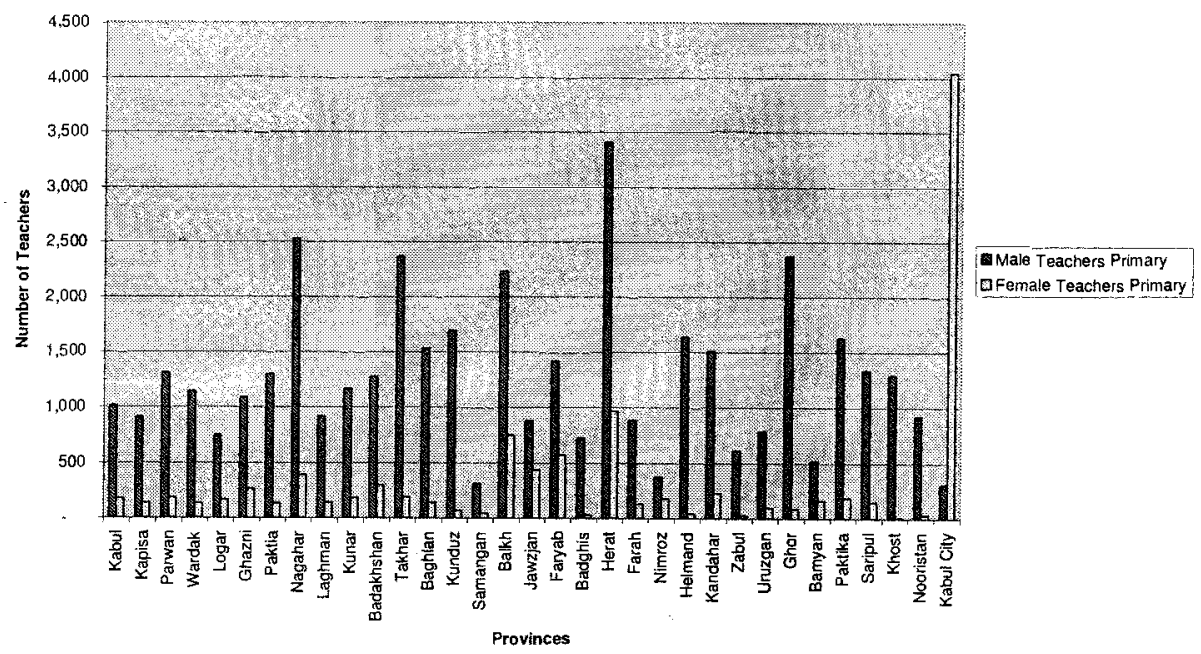


The male to female teacher ratio is quite different at the secondary school level, as shown below. In Badakhshan, Baikh and Kabul City there are more female teachers than male. The ratio of female to male teachers is not as high as the ratio of female to male teachers in the primary schools. However, there remains a shortage of female teachers in the south and southeastern provinces.

Figure 9: Comparison of Male and Female Secondary School Teachers by Province

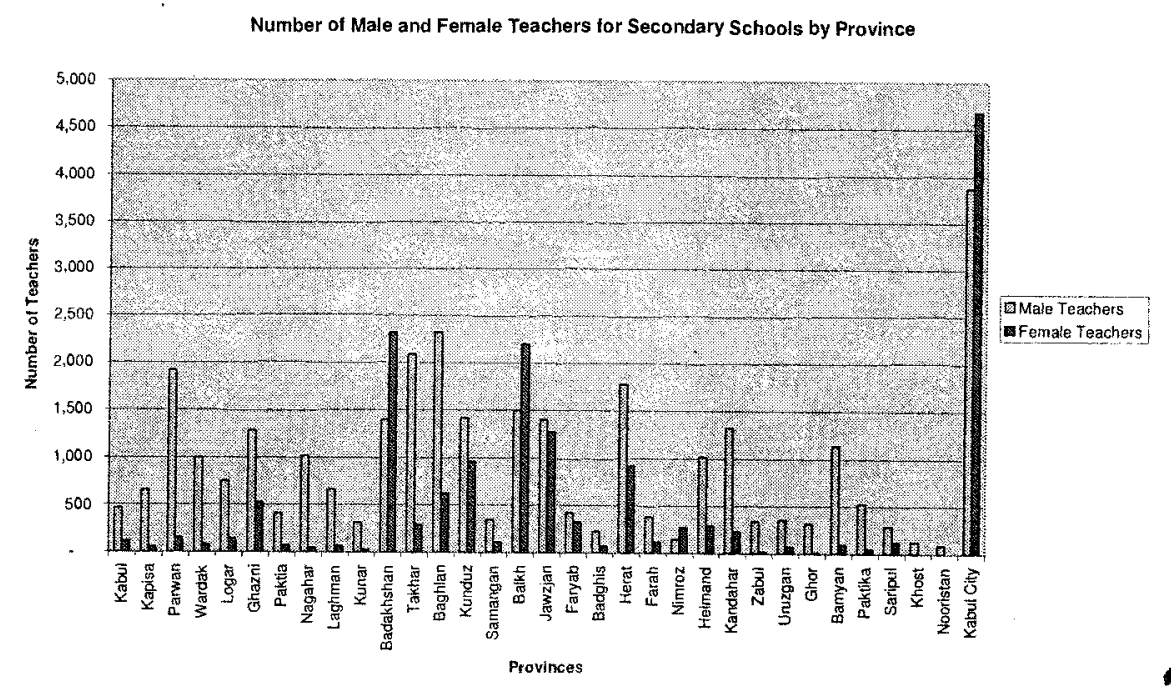

Teacher qualifications are also not accurately known. The MoE in the National Development Plan provides a table showing teacher qualifications. This table indicates that more than 50 percent of all teachers employed by the MoE have not graduated from grade 12 . A study of 3,332 teachers in Baghlan by the Aga Khan Development Network (AKDN) ${ }^{13}$ showed that almost ten percent of teachers surveyed had never attended any form of formal education. A short study conducted in the province of Balkh by $\mathrm{JICA}^{14}$ indicated that more than 65 percent of all teachers have as their highest qualifications grade 10 or less.

Given the lack of accurate data available for the numbers of teachers and the urgent need for such data to plan for future teacher training programmes, UNICEF is supporting the MoE to establish a national Education Management Information System (EMIS). This programme officially commenced in June 2004 and will include detailed information on numbers of teachers by school, qualifications and employment grades. Provincial and district education officials with technical training and support by UNICEF conducted the survey. The first set of completed survey forms have been received by the ministry and a team of 20 computer data entry staff are collating the information at the IT section of the MoE. It is anticipated that a complete set of data will be publicly available by the end of October 2004 .

\section{B.6 Formal and Non-Formal Teacher Education Programmes}

In Afghanistan there is sometimes confusion over the difference of formal or non-formal education programmes. The Human Rights Council's Report Card: Progress on Compulsory Education (Grades 1-9) states that the government should make it clear that it recognises nonformal education systems as part of the strategy to achieve education targets. This is also in

\footnotetext{
13 Agha Khan Development Network, Survey Results from the Rural Education Support Programme, Baghlan, Afghanistan, 2004.

${ }_{14}$ JICA, Teacher Survey, Balkh, Afghanistan, 2004.
} 
line with the 2015 Education for All goals. There is a range of different educational opportunities for children and adults in Afghanistan and teacher training programmes need to be targeted to address each of these different initiatives. The following gives a brief outline of some of the educational programmes currently ongoing in Afghanistan.

Figure 10: Summary of Formal and Non-Formal Education Opportunities

\begin{tabular}{|l|l|l|}
\hline Type of schooling & Target group & Formal or Non-formal \\
\hline Formal School (Grade 1-12) & School age children from 7 years & Formal (MoE) \\
\hline Accelerated Learning & $\begin{array}{l}\text { School age children who have } \\
\text { missed some years of school but } \\
\text { who plan to resume their education } \\
\text { Home-based Schools }\end{array}$ & $\begin{array}{l}\text { Formal (MOE, some training from } \\
\text { NGOs) } \\
\text { who cannot go to a formal school } \\
\text { but wish to continue their education }\end{array}$ \\
\hline Literacy Programmes & $\begin{array}{l}\text { Overage children or adults who } \\
\text { have limited or no education and } \\
\text { who will not be able to retum to the } \\
\text { formal education system }\end{array}$ & $\begin{array}{l}\text { Non-formal. Non examinable (MoE } \\
\text { Department of Literacy, NGOs, } \\
\text { community) }\end{array}$ \\
\hline
\end{tabular}

Formal education follows the MoE education curriculum, either in or out of school. This is examinable and therefore provides accreditation to the students to continue their studies. Non-formal is normally out of school, does not follow the MoE curriculum and is not examinable. Non-formal education is normally for overage children or adults who have very little or no education and who will never return to a formal school. Non-formal, or functional literacy programmes, are normally based on life skills learning and are developed around the specific interests of the learning groups, such as women, youth, ex-combatants, nomads or farmers.

Recently there has been a move to link teachers in home-based schools, who are teaching the formal curriculum, but who are not employed by the MoE, into MoE teacher training programmes. Linking the in-school and out-of-school activities may assist in expanding access to education for children who cannot go to school, as well as expand the teacher resource base of the MoE.

\section{Analysis Section B}

The MoE TTD has been active in designing and developing a model of expanded teacher training to include teachers from the rural areas. However, a concrete plan to improve the allocation and distribution of teachers will be very difficult without reliable school-based information that is effectively managed at the district, provincial and central level. The efforts of the ministry and UNICEF to establish an EMIS is a positive step, however, it is important that this information be fed back to the provinces and districts and that the information is continuously collected and updated. This will only be possible through an improved monitoring and evaluation system of the $\mathrm{MoE}$ at the provincial and district level through improved capacity of the MoE staff.

A number of different donor organisations have included in their overall plan a component of capacity building at the central, provincial and district MoE levels. As the National Development Budget states, "There is an urgent need to provide training and build capacity in project development, implementation and monitoring across the sector." Teacher education and professional development cannot be seen in isolation of the ministry system and the structure that they work within. UNICEF has been active in providing direct support to the $\mathrm{MoE}$ at all levels, in the way of training, supplies and technical assistance. The World Bank and some NGOs working in the sector of education have also been active in this area of support. It is not clear, however, what the actual capacities of the provincial and district 
education offices are. A detailed understanding of the needs, going beyond assistance in the way of supplies and administrative and financial training, could be considered. For example, the World Bank, in its negotiations with the MoE provincial directorates, has found that the most significant impediment to building a coordinated and efficient provincial level $\mathrm{MoE}$ structure is the lack of trust between staff members. Information sharing is still not something that happens easily. This factor is key when considering the need for effective information management.

Within this context of administrative reform, salary payments to teachers remain an area that deserves further attention. The World Bank is working closely with a small number of provincial departments to identify a more efficient and effective method of payments to the PEDs. At present, even after a budget has been approved, there is a long and arduous process for receiving funds from the revenue collector (the person representing the Ministry of Finance in the province). In some cases there are reports of teachers having to pay an unofficial "commission" to revenue collectors to be able to receive their salary cheque. Although the ministry has in place a system of data collection from the provinces, this system needs to be more fully understood and then built upon to strengthen its capacity. Currently all systems are hand written with no electronic data collection. At the central level, there remains no reliable source of data for the location and number of teachers. This raises the issue of how the teacher salaries are then distributed. Capacity building of the provincial and district offices also needs to be considered within the wider scope of the Public Service Reform programme for Afghanistan. The MoE cannot be seen in isolation from the Ministry of Finance, the Ministry of Planning and the Ministry of Labour and Social Affairs.

Recruitment of teachers with "qualifications" remains the preferred option of the ministry. Teachers may come from many different backgrounds or professions: mullahs, ex-combatants, farmers, traders, mothers and fathers. At present there is no systematic method for assessing whether the person has the right "competencies" to become a teacher. Some may argue that providing a learning environment for children with a teacher with harmful attitudes to teaching might in the longer-term be more detrimental to the learning needs of that child than if the child never attended school.

\section{TEACHER TRAINING PLANS AND ACTIVITIES}

\section{C.1 Government Support to Teacher Education}

The development of teacher capacities is one of the government's major priorities. The MoE has two strategies - for long- and short-term programmes - to support teacher training, as well as a third strategy that combines these programmes. The longer-term strategy involves support to the TTCs, including physical rehabilitation, provision of supplies and developing a new curriculum for pre-service teacher training. The MoE plans to establish a TTC in each of the 34 provinces in the country. This would require an additional 15 colleges, including the physical infrastructure, supplies and qualified teachers.

The shorter-term plan for teacher training includes a train-the-trainer concept, whereby a team of master trainers will be trained in Kabul, who will then train others in the provinces who in turn will train teachers in the districts. The plan is to ensure that all teachers undergo a basic rapid in-service teacher-training programme.

The third plan for the MoE is to establish Teacher Resource Centres (TRCs) in every district of the country. This plan is an effort to move teacher training programmes out of the urbanbased TTCs and into the districts and villages. The TRCs will not be a physical building in each district, but rather a small team of trained teachers who will become a resource base for 
support and supervision of teachers in their district. The TRCs therefore might then be referred to as Teacher Resource Groups.

The next section outlines the various MoHE and MoE supported teacher training facilities. This includes courses for short-term and long-term in-service (INSET) and pre-service (PRESET). Some detail is presented of the courses offered in each training facility and the specific subjects within these courses, which give some idea of what teachers learn when they complete these training courses or degrees.

There are four different types of teacher training facilities supported by the government in Afghanistan. It is sometimes not clear the exact role of each and their differences. The following table gives a brief outline of the types of facilities currently functioning, which ministry is responsible for each and what type of courses are available.

Figure 11: Summary of Government Teacher Education Facilities in Afghanistan

\begin{tabular}{|c|c|c|c|c|}
\hline $\begin{array}{l}\text { wame of } \\
\text { Instintion }\end{array}$ & $\begin{array}{l}\text { pesporstole } \\
\text { ministry }\end{array}$ & PRESET & 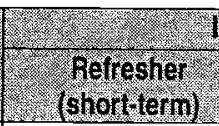 & 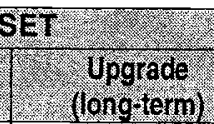 \\
\hline TTC & $\mathrm{MoE}$ & $\begin{array}{l}2 \text { years }(\mathrm{G} 13-14) \\
5 \text { years }(\mathrm{G} 10-14)\end{array}$ & None & 2 years \\
\hline $\begin{array}{l}\text { In-Service Regional } \\
\text { Centre/Teacher } \\
\text { Academy }\end{array}$ & $\mathrm{MoE}$ & None & None & 2 years \\
\hline $\begin{array}{l}\text { Institutes of Higher } \\
\text { Education }\end{array}$ & MoHE & 4 years & $\begin{array}{l}\text { Yes (not on a } \\
\text { regular basis) }\end{array}$ & 4.5 years \\
\hline $\begin{array}{l}\text { Universities Faculty } \\
\text { of Education }\end{array}$ & MoHE & $\begin{array}{l}4 \text { years (day) } \\
5 \text { years (evening) }\end{array}$ & None & None \\
\hline
\end{tabular}

\section{C.1.1 Teacher Training Colleges}

The TTCs throughout Afghanistan are administered and funded by the TTD of the central MoE in Kabul. There are currently 19 TTCs registered with the MoE. Three of these facilities are not currently operating. All of the functioning TTCs provide in-service teacher training, with the exception of Badakhshan, which only offers pre-service training. A total of 5,706 students are registered in pre-service $(1,465$ students) and in-service programmes $(4,241$ students). Some MoE staff believe that the TTCs should only offer in-service teacher training and only pedagogical institutes or universities offer pre-service. This is not currently the case and is not widely supported by all MoE staff.

Figure 12: Summary of PRESET and INSET Students at TTCs

\begin{tabular}{|c|c|c|c|c|c|c|c|c|c|c|}
\hline \multirow{2}{*}{ No } & \multirow{2}{*}{ TTC } & \multirow{2}{*}{$\begin{array}{c}\text { Year of } \\
\text { foundation }\end{array}$} & \multicolumn{3}{|c|}{ PRESET students } & \multicolumn{3}{|c|}{ INSET students } & \multirow{2}{*}{$\begin{array}{c}\text { Teachers } \\
\text { Total }\end{array}$} & \multirow{2}{*}{$\begin{array}{l}\text { Building } \\
\text { Type }\end{array}$} \\
\hline & & & Male & Female & Total & Male & Female. & Total & & \\
\hline 1 & $\begin{array}{r}\text { Sayed } \\
\text { Jamaludeen }\end{array}$ & 1909 & 474 & 285 & 759 & 287 & 730 & 1017 & $47^{15}$ & TTC \\
\hline 2. & Laghman & 1988 & 137 & 1 & 138 & 135 & 27 & 172 & 12 & TTC \\
\hline 3 & Baghlan & 1991 & 43 & 1 & 44 & 450 & 410 & 860 & 12 & TTC \\
\hline 4 & Paktia & 1968 & 16 & 0 & 16 & 52 & 21 & 73 & 7 & TTC \\
\hline 5 & Takhar & 1977 & 18 & 0 & 18 & 226 & 175 & 401 & 5 & Rental \\
\hline 6 & Kunduz & 2003 & 0 & 0 & 0 & 30 & 153 & 183 & 14 & Rental \\
\hline 7 & Farah & 2002 & 0 & $\underline{0}$ & 0 & 50 & 55 & 105 & 6 & $\overline{T T C}$ \\
\hline 8 & Nimroz & 2002 & 0 & 0 & 0 & 80 & 105 & 185 & 10 & Rental \\
\hline 9 & Badghis & 2003 & 0 & 0 & 0 & 125 & 72 & 197 & 8 & Rental \\
\hline 10 & Kandahar & 1968 & 0 & 0 & 0 & 61 & 46 & 107 & 7 & TTC \\
\hline
\end{tabular}

\footnotetext{
${ }^{15}$ At Sayed Jamaldeen College there are almost as many cleaning staff employed by the college as
} there are teachers. In addition there are 13 administrative staff working for the college. 
1.

\begin{tabular}{|r|r|r|r|r|r|r|r|r|r|r|}
\hline 11 & Helmand & 1977 & 0 & 0 & 0 & 54 & 55 & 109 & 4 & TTC \\
\hline 12 & Samangan & 2003 & 38 & 5 & 43 & 66 & 46 & 112 & 15 & Rental \\
\hline 13 & Badakhshan & 1996 & 242 & 78 & 320 & 0 & 0 & 0 & 19 & TTC \\
\hline 14 & Kapisa & 2002 & 113 & 2 & 115 & 296 & 94 & 390 & 20 & TTC \\
\hline 15 & Ghazni & 2003 & 9 & 3 & 12 & 90 & 100 & 190 & 12 & Rental \\
\hline 16 & Sar Pol & 2003 & 0 & 0 & 0 & 59 & 81 & 140 & 10 & Rental \\
\hline 17 & Jawzjan & 2004 & 0 & 0 & 0 & 0 & 0 & 0 & 0 & Rental \\
\hline 18 & Herat & 2004 & 0 & 0 & 0 & 0 & 0 & 0 & 0 & TTC \\
\hline 19 & Parwan & 2004 & 0 & 0 & 0 & 0 & 0 & 0 & 0 & TTC \\
\hline
\end{tabular}

(Source: Department of Teacher Training MoE, 2004 \& Mr Takahashi, JICA Education Consultant, 2004)

Individual TTCs are supported by different organisations. For example, the TTC in Kabul was rehabilitated with USAID funding. UNICEF will provide support for supplies for libraries, computers, furniture and generators for four TTCs in Laghman, Kandahar, Helmand and Takhar. It is planned to expand this support to Nangahar and Samangan. ${ }^{17}$ At this stage, UNICEF plans no technical support to the TTCs. AKDN supports the TTC in Badakhshan and Baghlan. AKDN has provided funds for physical rehabilitation of the facilities and supplies for laboratories and libraries, but most importantly has provided technical support through the appointment of international staff stationed full time at each of the TTCs. Also, for the two TTCs that AKDN is supporting, the Indian government will provide in-kind support in the way of solar panels for electricity to the buildings, computers for an IT section, and staff to provide training for the IT programme and English language department.

- Pre-service

Nine of the total 16 operational TTCs offer pre-service teacher training programmes. Thus pre-service programmes account for only a quarter of the total number of TTC students. Of these, almost half of all the students are in the Kabul TTC, Saged Jamaludeen. This TTC also has 75 percent of the total number of female students countrywide ( 285 of a total of 375 ). The only other TTC that has a significant number of female students is Sheghnan TTC in Badakhshan. Four other TTCs have female students. These include Laghman, Baghlan, Samangan, Kapisa and Ghazni. However, the highest enrolment rate in any of these colleges is five female students. Most TTCs throughout the country are in urban centres, so without boarding facilities it is very difficult, especially for female students, to move away from their family and attend college.

The process of registration for pre-service teacher training depends on the final result of the University General Entrance Exam (Concur exam) taken by grade 12 graduates. Each student can select four college preferences. Only the students with the highest results will be accepted into Kabul University. Normally those students with the lowest results are accepted into TTCs. A student may select which TTC he or she prefers to study at. Normally students will select the TTC closest to their home, or the Kabul TTC.

There are two types of pre-service training courses - a two-year course and a fiveyear course. The two-year course is the equivalent of grade 13 and 14. The admission to this course is outlined above. The second course is a five-year course for students leaving grade 9 . There is limited demand for this type of course and it is only offered at Kabul Sayed Jamaludeen College. Of the total number of students in this TTC,

\footnotetext{
${ }^{16}$ These figures can only be considered a guide. Without personal visits to each of the TTCs it is impossible to know the exact figures. For example, AKDN state that the actual number of students for Badakhshan TTC is over 500, where as the MoE record a figure of 320 .

${ }^{17}$ The Japanese government under the Ogata III initiative funds this project. Total project value is approximately US\$1.6 million.
} 
only 8 are registered in the five-year course. The Department of Teacher Training at the MoE would like to expand this five-year course, as they feel that the quality of graduates from this would be better than the graduates from the two-year course. For both courses students will have completed 14 years of education.

There are 12 different departments within the TTCs throughout Afghanistan. However, in most TTCs not all subjects are offered. All 12 subjects are outlined in the table below. For Sayed Jamaludeen TTC, there are currently no students or teachers for Pashto language studies or religious/Islamic studies. English language has the highest demand for new entrants.

Figure 13: The list of departments for the pre-service courses at Sayed Jamaludeen

\begin{tabular}{|l|l|}
\hline Functioning Departments & Non-functioning Departments \\
\hline 1. Dari Language & 8. Religious Studies \\
\hline 2. English Language & 9. Pashto Language \\
\hline 3. History & 10. Physics \\
\hline 4. Geography & 11. Physical Education \\
\hline 5. Chemistry & 12. Kindergarten (pre-primary education) \\
\hline 6. Mathematics & $\cdot$ \\
\hline 7. Biology & \\
\hline
\end{tabular}

In each of the departments, there are a total of 18 subjects included in the curriculum. Nine of these subjects are specific to the area of study. Another nine subjects are general education subjects and are common to all departments. These common subjects are provided through the Department of Professional Education (Department of Pedagogy). This is a separate department within the TTCs. An example of the Mathematics Department curriculum is outlined in figure 14.

Figure 14: Example of set of subjects of one department in a TTC (Mathematics) No Subject

\begin{tabular}{|c|c|c|c|}
\hline 1 & General Mathematics & 12 & 8 \\
\hline 2 & Analysis of Mathematics & 8 & 8 \\
\hline 3 & Algebra & 8 & 8 \\
\hline 4 & Theory of Numbers & 8 & 8 \\
\hline 5 & Mechanical Physics & 8 & 4 \\
\hline 6 & Electronic Physics & 8 & 4 \\
\hline 7 & Geometry and Analytic Geometry & 12 & 8 \\
\hline 8 & Optic Physics & 8 & 4 \\
\hline 9 & Teaching of Mathematics & 8 & 4 \\
\hline \multicolumn{4}{|c|}{ Common subjects in all departments } \\
\hline 10 & Principles of Education & 12 & 8 \\
\hline 11 & Fundamentals of Administration & 4 & 2 \\
\hline 12 & Teaching & 8 & 2 \\
\hline 13 & Psychology & 14 & 6 \\
\hline 14 & Evaluation and Examination & 6 & 2 \\
\hline 15 & Teaching Technology & 4 & 4 \\
\hline 16 & Foreign Language (English) & 8 & 8 \\
\hline 17 & Islamic Culture & 4 & 4 \\
\hline 18 & Peace Studies ${ }^{18}$ & 4 & 4 \\
\hline
\end{tabular}

Note: a) PRESET: 6 session/day $\times 6$ days/week $\times 16$ weeks b) INSET: 4 sessions/day $\times 6$ days/week $\times 21$ weeks. (Source: Sayed Jamaludeen Teacher College Kabul, 2004)

\footnotetext{
${ }^{18}$ There is some confusion over whether or not peace studies is actually offered to the students. In other examples of curricula shown to the AREU research team, physical education and mother tongue language skills are offered instead.
} 
There are either very few or no teacher books available for any of the subjects taught in the TTCs. Normally a teacher has a very poor photocopy of a handwritten selection of papers. Even in the largest and most well equipped TTC in Kabul, no students had any textbooks or learning materials. The teaching materials available to the TTCs are all very poor.

Attached to two of the TTCs are experimental schools. These schools are managed and administered directly by the district education office of the MoE. In the second year of study students who attend a TTC that is connected with an experimental school take a subject in "practical teaching" and spend several hours a week observing and participating in class activities in these schools.

Students who achieve results of 90 percent or more in their final examinations at the TTCs are eligible to be considered for entry into the second year of a four-year degree at Kabul University. Students who are enrolled in a TTC course can be considered for a teaching position. These students are then eligible to transfer to an in-service course. In-service students are not eligible to transfer to a pre-service course, as entry to preservice is governed by the Concur examination. Last year almost 1,200 grade 12 students qualified to attend TTCs, however, only a third of these students actually enrolled. It is assumed that many students could not provide the means to stay away from home and continue their studies. Also, in many cases, students did not enrol because they did not value teaching as a viable career path.

$$
\text { - In-service }
$$

Almost 75 percent of all TCC students are in-service. ${ }^{19}$ Almost a quarter of these students are in Kabul Sayed Jamaludeen TTC. Of all the TTC in-service students, the ratio of female to male students is almost 50:50 (2,061 male, 2,180 feamle), Inservice training is available in 15 of the operational 16 TTC facilities. Only Badakhshan does not provide in-service teacher training. Of the 1,017 students enrolled in Kabul Sayed Jamaludeen College, 71 percent are women. Considering that the only boarding facilities available to the TTC are for men, it is assumed that most of these female students are from Kabul.

All full-time teachers are eligible to be accepted into an in-service teacher training programme at a TTC. Teachers are required to complete a registration form and seek approval from the school principal. In-service courses are normally available in the morning or afternoon. In some cases, in-service training is also available in the evening.

The curriculum of the in-service teacher-training course is almost exactly the same as pre-service courses. There are less contact hours for in-service courses; however, the semesters are slightly longer ( 21 weeks compared to 16 weeks for pre-service). Teachers attend pre-service courses during the time of the day when they are not working.

Students completing an in-service training course may be considered for entrance into Kabul University if they achieve an average result of above 90 percent. However, unlike pre-service students, in-service students must complete two further years of full time teaching after graduation before being considered for entrance into the university.

\footnotetext{
${ }^{19}$ This does not include students attending in-service regional centre colleges, explained in the following section.
} 
UNICEF, through Teachers College, Columbia University (TCCU), is working closely with a team of people at the MoE and TTCs to develop a new curriculum and teacher materials for pre-service teacher training. Eight teacher standards have been developed from the national student curriculum framework document completed in 2003. From these eight teacher standards, which encompass what a teacher needs to know, do and possess, a new TT curriculum is being developed. A team of 16 Afghan professionals worked with the TCCU to finalise the standards and a team of 32 Afghan professionals working with TCCU are working to complete the new curriculum framework. The syllabus for the new curriculum is in the final stages of completion. It is expected that much of the syllabus for the teacher training materials could be completed in the next 12 months. UNICEF will continue to focus its support on pre-service teacher training for basic education (grade 1-9 students), however, this programme is not yet fully funded.

JICA, as a part of STEP (Strengthening Teacher Education Programme) from next year, will build on the work of TCCU to develop the in-service teacher training materials. They plan to develop a syllabus for teacher training that can be taught partially by face-to-face contact and partially through distance education. The technology of Equal Access will be drawn upon to achieve this.

\section{C.1.2 In-service regional centres}

The In-Service Regional Centres are an extension of the TTC in-service teacher training programme. They are not based at a TTC, but in a school, which is linked to a TTC. They conduct the same two-year in-service training that is provided by the TTC. Although they are called regional centres, there are in fact only six centres, five of which are in Kabul. There is also one in-service regional centre in Andkhoy in the north of Afghanistan. The concept behind the in-service regional centres is to expand the TTCs into areas where teachers wuld otherwise not be able to attend a teacher training course. It is the concept of these centres on which the idea of Teacher Resource Centres has been developed.

Figure 15: Summary and Location of In-service Regional Centres

\begin{tabular}{|l|l|l|l|l|l|}
\hline \multirow{2}{*}{ No } & In-service Regional Centre & \multicolumn{3}{|c|}{ INSET Students } & Teachers \\
\cline { 3 - 6 } & Male & Female & Total & \\
\hline 1 & Isteglal High School & 109 & 408 & 517 & 34 \\
\hline 2 & Naderia High School & 105 & 213 & 318 & 18 \\
\hline 3 & Alfatha High School & 75 & 366 & 441 & 23 \\
\hline 4 & Maryam High School & 126 & 575 & 701 & 35 \\
\hline 5 & Hazrat Ibrahim High School & 26 & 83 & 109 & 12 \\
\hline 6 & Andkhoy & 75 & 185 & 260 & 24 \\
\hline \multicolumn{2}{l}{ TOTAL } & 516 & 1830 & 2346 & 146 \\
\hline
\end{tabular}

(Source: AREU Research Team Visits to Site, 2004, JICA Education Consultant, 2004)

There are a total of 2,346 students attending in-service regional centres. Seventy-eight percent of these students are female and in every centre there are more women than men. Normally the trainers for the regional centres come from the TTCs. There are a total of 146 teachers for all the regional centres.

It is planned that the in-service regional centres will become a part of the Teacher Training Academy (TTA). The TTA will be a complimenting department of the TTD and will focus on in-service teacher training. The in-service regional centres will be expanded to include a Teacher Resource Centre (TRC), or group, in each district across Afghanistan. Each TRC will include between 6-12 master trainers. These trainers, who will participate in a one month intensive teacher training programme, will become a mobile component of the provincial and district education office and provide teacher support and supervision in the specific cluster of 
schools to which they are responsible. UNICEF supports this concept, however, funds have not been allocated to this programme and no specific project details of implementation have been agreed upon. An outline of the MoE vision for TRCs is attached in Annex B.

\section{C.1.3 Institutes of Higher Education/Universities}

There are three types of higher education facilities that offer teacher training and education studies. All institutes offer four-year degrees in education or pedagogy. These include pedagogical institutes (now phasing out), IHEs and universities. During the Soviet occupation "pedagogical institutes" were introduced as education facilities providing four-year programmes of study in traditional disciplines. Six TTCs in the major population centres were transferred to the Ministry of Higher Education to become pedagogical institutes, including the facility in Kabul. The Kabul Pedagogy Institute was elevated in 2002 and renamed as the University of Education. Now most pedagogical institutes have become IHEs. These IHEs follow a similar curriculum to the Kabul University of Education. In Parwan, there remains a pedagogical institute. The IHEs' and Pedagogical Institutes' main purpose is to produce teachers for junior secondary and upper secondary schools. At this time, the MoHE is going through a transitional period, where institutes and universities' status is still being identified and finalised.

\section{- Institutes of Higher Education / Pedagogical Institutes}

There are five major faculties within the curriculum of the University of Education. Within each faculty there are a number of departments. The professional education faculty serve the other four faculties for in-service teacher training and core education curriculum subjects.

\section{Figure 16: List of Faculties for Higher Education Institutes}

\begin{tabular}{|c|c|c|}
\hline No & Faculty & Departments \\
\hline 1 & Faculty of Natural Science & $\begin{array}{l}\text { Mathematics } \\
\text { Physics } \\
\text { Chemistry } \\
\text { Biology }\end{array}$ \\
\hline 2 & Social Science & $\begin{array}{l}\text { History } \\
\text { Geography } \\
\text { Islamic Studies } \\
\text { Anthropology }\end{array}$ \\
\hline 3 & Language & $\begin{array}{l}\text { Dari } \\
\text { Pashto } \\
\text { English } \\
\text { Arabic } \\
\text { Russian }\end{array}$ \\
\hline 4 & Physical Education & Health and Physiology \\
\hline 5 & Professional Education & $\begin{array}{l}\text { In-service Teacher Training } \\
\text { Core Curriculum for all other subjects }\end{array}$ \\
\hline
\end{tabular}

Each department includes a total of 35 subjects. This includes 19 professional subjects as well as a set of core curriculum subjects offered by the department of professional education. These core subjects are as follows:

\section{Figure 17: List of Core Subjects for Each Department in the Institutes}

\begin{tabular}{|l|l|l|l|}
\hline Education Technology & Psychology-general & Teaching psychology & $\begin{array}{l}\text { Psychology of } \\
\text { Learning }\end{array}$ \\
\hline
\end{tabular}

\footnotetext{
${ }^{20}$ Anthropology will be offered as a degree for students from the start of 2005.
} 
2.

\begin{tabular}{|l|l|l|l|}
\hline $\begin{array}{l}\text { Basic History of } \\
\text { Education }\end{array}$ & $\begin{array}{l}\text { Teaching } \\
\text { Methodologies }\end{array}$ & $\begin{array}{l}\text { Curriculum } \\
\text { Methodologies }\end{array}$ & Test and Measurement \\
\hline $\begin{array}{l}\text { Practical Teaching } \\
\text { Research } \\
\text { Methodologies }\end{array}$ & Islamic Studies & Peace and Democracy & $\begin{array}{l}\text { Environment and } \\
\text { Health }\end{array}$ \\
\hline
\end{tabular}

Figure 18: List of Pedagogical Institutes and Institutes of Higher Education

\begin{tabular}{|l|l|l|l|l|}
\hline & Name of Institute & $\begin{array}{c}\text { Pre-service } \\
\text { Training }\end{array}$ & $\begin{array}{c}\text { In-service } \\
\text { Training }\end{array}$ & \multicolumn{1}{|c|}{ Location } \\
\hline$\frac{1}{2}$ & University of Education & Yes & Yes & Kabul \\
\hline 3 & Fadakhshan IHE & Yes & Not known & Badakhshan \\
\hline 4 & Jawzjan IHE & Yes & Not known & Faryab \\
\hline 5 & Baghlan IHE & Yes & Not known & Jawzjan \\
\hline 6 & Kunduz Pedagogical Institute & Yes & Not known & Baghlan \\
\hline 7 & Parwan Pedagogical Institute & Yes & Not known & Kunduz \\
\hline 8 & Herat IHE & Yes & Not known & Parwan \\
\hline
\end{tabular}

The International Rescue Committee (IRC) is providing support to the IHE in Herat. This includes training for staff, provision of IT equipment and other essential supplies. Administrative systems of the institute and out of date teacher qualifications and experience continue to be major issues for capacity building.

The IHEs and universities are administered directly by the MoHE. They do not depend on the financial support of the PEDs as their funding comes directly from the MoHE in Kabul. There is limited if any coordination between the universities, the IHEs and the TTCs.

\section{ㅁ Universities}

All universities have an education faculty. There are two departments within the education faculty at the universities. They offer four-year degrees in psychology and pedagogy. From 2005 they hope to offer degrees in library science, educational administration and clinical psychology also within the education faculty. As yet, no teachers for these new degrees have been identified. The universities' aim is not to produce teachers, but senior administrators and technical specialists in the area of education. However, four universities in the provinces offer in-service teacher training. The number of students in each of the universities within the education faculty is not currently known by the central MoHE. Although there are two specific departments offering degrees related to education, all graduates from the universities may be considered directly for a teaching position. Other faculties within the universities, such as law, medicine and engineering, do not offer any educational or pedagogical subjects for students who may later become a teacher. Below is a list of all universities functioning across Afghanistan.

Figure 19: List of Universities in Afghanistan

\begin{tabular}{|l|l|l|l|l|}
\hline & Name & $\begin{array}{c}\text { Faculty of } \\
\text { Education }\end{array}$ & $\begin{array}{c}\text { In-service } \\
\text { Training }\end{array}$ & \multicolumn{1}{|l|}{ Location } \\
\hline 1 & Kabul University & Yes & None & Kabul \\
\hline 2 & Nangarhar University & Yes & Yes & Nangarhar \\
\hline 3 & Balkh University & Yes & Yes & Balkh \\
\hline 4 & Al-Bruni University & Yes & No & Kapisa \\
\hline 5 & Herat University & Yes & No & Herat \\
\hline 6 & Kandahar University & Yes & No & Kandahar \\
\hline
\end{tabular}




\begin{tabular}{|l|l|l|l|l|}
\hline 7 & Paktia University & Yes & No & Paktia \\
\hline 8 & Khost University & Yes & No & Khost \\
\hline 9 & Takhar University & Yes & Yes & Takhar \\
\hline 10 & Bamyan University & Yes & No & Bamyan \\
\hline
\end{tabular}

\section{C.2 International Organisations Support to Teacher Training ${ }^{21}$}

\section{C.2.1 UNICEF/Teachers College, Columbia University}

UNICEF has been active in supporting the MoE for teacher training in Afghanistan since 2002. In the winter of $2002 / 2003$ UNICEF provided technical and financial assistance to the MoE to implement a rapid teacher-training programme of almost 20,000 teachers across the country. This training, which was based on learning and teaching language and arts, utilised story telling and role-play as the key tool in classroom teaching. The training, which lasted for eight days, had the significant effect of raising the morale of teachers and gave them a taste of new and more interesting ways of teaching and raised their interest in the learning needs of children. The training was in no way intended to be a first and final training programme, but was instead an emergency response to a request by the MoE. Since this time, at the request of the ministry, UNICEF has expanded this programme over the summer and winter teaching breaks to cover almost 50,000 teachers.

For the longer term, UNICEF is funding an agreement with TCCU to work with the TTD to develop a new teacher training curriculum and syllabus. This is being done concurrently with the development of new children's textbooks in partnership with the Department of Compilation and Translation (Department of Curriculum) in the ministry. It is hoped that the teacher training materials will be complete for printing in the next 12 months. The implementation of the new materials and training for the teachers will be the next challenge.

UNICEF plans to develop a very large-scale girls education project, which will include 10,000 home-based schools in nine different provinces. These will include Parwan, Faryab, rural Kabul, Takhar, Ghazni, Herat, Farah, Badghis and Nangarhar. Kandahar is also planned depending on the security environment. The programme, which will be administered directly through the PDEs and DDEs, will cover 10,000 teachers. The community-based teacher training curriculum has been developed and is based on the principles of language arts training that were used during the first winter teacher training programme of 2002-2003. The details of the implementation of this plan and funding for the initiative have not yet been finalised.

\section{C.2.2 TEP Rapid Teacher Training Programme}

The Teacher Training Department at the MoE has declared a "state of emergency" for rapid teacher training for 105,525 teachers in Afghanistan - to be completed by the end of 2004 . This programme will be conducted over a period of 80 hours, which can be taken full time (13 days) or part time ( 26 days). The training will be conducted using training of trainers methodologies and will build on the same principles as the emergency winter teacher training programme from 2002/2003. A detailed project outline for the implementation of this programme has not been finalised, however, teachers are already being identified at the provincial and district level to be included in the programme. DANIDA and the World Bank have expressed their willingness to financially support an acceptable final project plan. UNICEF and CAII have worked closely with the MoE to develop the plan.

\footnotetext{
${ }^{21}$ This section may not include the teacher training programmes of all organisations. Time limitation prevented more extensive interviews with all organisations.
} 


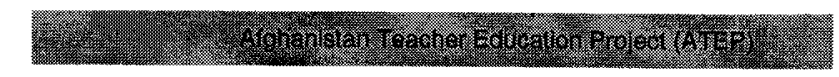

\section{C.2.3 World Bank}

The World Bank in August 2004 approved a grant of US\$37 million for the education sector in Afghanistan over the next four years. These funds will be channelled through the MoE. The Education Quality Improvement Programme (EQUIP) aims to improve the quality of educational inputs and processes as a foundation for a long-term strategy to improve the quality of educational outcomes. This will be achieved through: 1) focus on schools and communities to strengthen their capacity to better manage teaching-learning activities; 2) the investment in human resources (teachers, principals and educational administration personnel) and physical facilities; and 3) policy development. Teacher training (US\$7 million), training of school principals (US\$1.5 million), and capacity building of provincial and district education departments (US\$3 million) is included in the second component. The US $\$ 7$ million included in the teacher training activity could be used to support the development of the new teacher training curriculum and to work with the teacher colleges to implement a national in-service teacher programme. The grant should be seen as a package to include support to the provincial and district education offices, rather than as a separate allocation of funds for teacher training. (Details of the grant are included in Annex C.)

\section{C.2.4 ADB Rural Education Project}

The Asian Development Bank (ADB), with funding from the government of Japan, has allocated US\$4 million over two years for Community-Based, Gender Sensitive Basic Education for the Poor. Utilising the "whole school" approach, the project's aim is to explore and pilot mechanisms for effective partnerships between government, schools, NGOs and communities in the development and implementation of innovative basic education services. A consortium of NGOs led by CARE Afghanistan includes Save the Children, US (SC/US), IRC and Catholic Relief Services. The programme works in areas that the MoE already has a presence, however, the main goal of the programme is to re-establish community links with the schools, to raise awareness of the importance of education, and to illustrate the importance and value of community involvement in the education of children. The programme works to build linkages between community schools where there is a MoE presence and the provincial and district education departments. The programme works in four different provinces: Parwan, Paktia, Paktika and Faryab. It is planned that this initiative, which currently includes approximately 100 schools, be expanded to a further two provinces. Although the total number of schools and teachers involved in this programme may be comparatively small, it is very intense, requiring ongoing support and training to community members and education authorities.

\section{C.2.5 Creative Associates APEP Accelerated Learning Programme}

CAII as a part of their Afghanistan Primary Education Programme (APEP) is supporting the $\mathrm{MoE}$ to provide training to teachers to conduct accelerated learning classes for over age students. This programme was first initiated with UNICEF and the Bangladesh Rural Advancement Committee (BRAC) at the end of 2002. Since then CAII with their key partner Children in Crisis (CIC) have taken the lead on this training. The programme is working with five local implementing partners, including Afghan Women's Education Centre, Coordination of Humanitarian Assistance, Afghanistan Development Association, Development and Humanitarian Services for Afghanistan and CORA. Since 2003 approximately 6,000 teachers have been trained. A further 800 teachers are planned to be included in the training programme.

\section{C.2.6 CARE COPE Project}

The CARE COPE project focuses on providing a community-based school to areas that have no school. It aims to increase access to education especially for girls, but to ensure that these new schools are managed and supported by the community in which the school functions. In 2003 the project, through the establishment of Village Education Councils (VECs) covered 26,478 students $(63 \%$ girls) in 371 community-managed schools in Khost, Paktia, Logar, 
Kabul, Maidan Wardak, Ghazni, Parwan, Kapisa and Paktika. The programme includes community support to 635 teachers. No salary is paid to the teacher, who is instead fully supported by the community through cash and in-kind gifts. The programme has been operating since 1994 and has been continuously expanding since this time. Once the school is established in a community, the COPE programme works towards handing over the school to the MoE. COPE has conducted a range of training programmes on teacher development for teachers, school management by community leaders, and administration and management for provincial MoE staff.

\section{C.2.7 AKDN Rural Education Support Programme}

This programme is funded entirely by the Swedish government. Its aim is to provide support for 132 schools in three provinces in Baghlan, Badakhshan and Bamyan. The programme is working in partnership with the $\mathrm{MoE}$ and includes aspects of provincial and district education office capacity building, school principal training, teacher training and classroom monitoring. The programme will train 400 teachers per year for three years in an initial one-month training programme with ongoing follow up training and evaluations. The programme will provide materials directly to the schools, including science kits, sports kits, children's storybooks and music kits. The ideology behind the teacher training is to base the training on something concrete that the teachers can use and practice with. AKDN found that previous teacher training programmes based on traditional lesson planning and classroom management did not result in visible changes at the classroom level. Teachers continued to use the same books and materials they used before and therefore quickly reverted back to their previous methodology of teaching.

\section{C.2.8 IRC Teacher Training Programme}

IRC has been implementing a teacher training programme in Afghanistan for the past seven years. Like many of the NGOs operating in Afghanistan, their programme moved from community-based, non-MoE teachers to $\mathrm{MoE}$ teacher staff. IRC is working in five different provinces including Nangahar, Paktia, Kabul, Logar and Herat. Their teacher training package has been built on the experiences of IRC in teacher training in Pakistan but revised and updated for the needs of the teachers in Afghanistan. The training materials include a comprehensive package of modules covering subjects such as: pedagogy, language, psychosocial, maths, training on material development, gender, management and administration, education planning, monitoring and evaluation, literacy, library management, awareness campaigns, religious and community leaders training, and ECD. IRC's teacher training programme has covered almost 3,000 teachers, including teachers employed by the $\mathrm{MoE}$ and home-based teachers. An impact evaluation of this programme is currently being set up, the results of which should be available by the end of 2004 .

\section{C.2.9 BRAC Community-Based Schools}

BRAC supports two programmes for teacher training. One is the UNICEF funded accelerated learning teacher training programme and the second is the Swedish International Development Cooperation Agency (SIDA) supported community-based schools programme. BRAC has extensive experience in community- and home-based schools in Bangladesh and is building on this experience to support teacher training in Afghanistan.

The accelerated learning programme has been conducted in nine provinces. The programme since the winter of 2002 has trained approximately 2,500 teachers so they may teach mainly overage students one year of school in the three month winter and summer breaks. The curriculum is based on language arts training, building on traditional story telling and mine awareness information.

The community-based school programme operates where there is no school supported by the MoE. It focuses on providing schooling for girls and therefore the large proportion of the 
teachers involved in the teacher training programme are female. The programme is functioning in Nangarhar, Parwan and Balkh. BRAC requires that teachers should at minimum have passed their grade 8 exams. The programme currently includes 83 teachers. The teacher training programme includes a one-day follow-up training every month. This programme also aims to build the linkages between the community-based teachers and the district and provincial education authorities. The curriculum used for the teacher training is very similar to the accelerated learning programme.

\section{Analysis Section C}

At present two different ministries provide teacher training programmes, however, there is little if any systematic coordination between them. This means that an understanding of the number of teachers going through teacher training facilities and where they hope to find employment is not known. In the previous analysis section of this document, teacher allocation was highlighted as one of the key factors for student teacher ratios. A better understanding needs to be developed at the central level of both the MoE and MoHE of where the greatest shortage of teachers is and what can be done to overcome this. Planning for this must be done jointly. The MoE could also share with the IHE pedagogical departments the curriculum that is being developed for teacher training colleges. Although logistically, and even politically, difficult, there may be opportunities for members of the pedagogical departments from the IHEs to be included in the development of the teacher training materials.

The TTCs at present offer a separate diploma for "kindergarten teaching." This department is not currently functioning, but it raises the issue of the availability of training programmes for multi-grade teaching and training teachers for either lower or upper primary school or secondary school within the government institutionalised system. In many classes in Afghanistan, the age difference of many of the students can be up to ten years, with many students having missed much of their education. Currently, teachers are not being trained to teach a specific learning level of students.

The TTC curriculum is currently based heavily on theory, with limited if any practical training. Only two experimental schools exist, but even without these schools, there are still many opportunities for teachers to practice and demonstrate different learning exercises with other fellow classmates in their course. Most courses remain taught in a rote learning lecture style, however, similar to the type of teaching found in schools.

In the past, the TTCs have been criticised for being a post-Soviet style "institution" rather than a learning environment. Despite this, the TTCs are providing a valuable resource to the ministry to develop a structured system of teacher training. TTCs are managing to function under very difficult circumstances and this in itself must be seen as a commitment by individuals throughout the provinces to expand the learning and training opportunities of teachers across the country. However, there remain a number of constraints to the operation of the TTCs that must be considered in an overall plan to support teacher education in the country. TTCs are poorly supported and require urgent technical and physical assistance so that they are able to provide the type of teacher training envisioned by the central MoE. In the case of one TTC, it is reported that students may repeat several times their two-year degree even though they have passed and qualified from the TTC already. This results in fewer places for new students wishing to be included in the TTC programmes. There are also extensive reports of financial benefits being paid to the staff of some TTCs to ensure that a particular student can pass their exams. Teacher who work "part-time" at the TTC also remain somewhat of a mystery. Although part-time teachers are registered as working, they are not in fact ever seen at the college by international technical support staff who are working fulltime at the college, although the college continues to receive financial support from the Provincial Education Department to pay these part-time salaries. Attendance records at the TTCs are sometimes questionable. On one occasion the records of one of TTC was more 
closely inspected by a staff person of one of the organisations supporting the facility and found attendance of all staff to be almost $100 \%$. This included a full attendance record of all staff over the five days of Eid.

From the above reports, a stronger monitoring and evaluation system is needed, one that not only checks attendance sheets, but whether the teacher is physically in the teaching college as reported. The $\mathrm{MoE}$ has a recognised monitoring and evaluation system, which is also applicable to the TTCs. However, this is not always effectively utilised or implemented. Also information collected as a part of the monitoring is not effectively fed back to the provincial or central MoE offices. Most reports are hand written with very little electronic communication between the provinces and the centre. There may be some possibility to put the TTCs on-line, not only for communication and monitoring purposes, but also so trainers may have access to more information on the Internet, given the very scarce availability of resource materials.

Boarding facilities in the TTCs have also seen some complications. International organisations have provided financial support to some TTCs to rebuild a boarding facility on the campus for either only women, or for women and men. In all cases, the TTC has then used the boarding campus for male students only, stating there was not enough space for women boarders. One of the newly rebuilt boarding campuses at a TTC was especially built with separate living quarters, separate kitchen, dining area, bathrooms and study areas for male and female students. However, this campus today is used only for men.

Although all TTCs in theory report directly to the Department of Teacher Training in MoE Kabul, all financial support to TTCs still comes via the PED. The relationship with the TTC and the PED is therefore still quite strong. PEDs as well as the Teacher Training Department in $\mathrm{MoE}$ are able to make recommendations to the Minister to appoint or remove senior level staff at the TTCs. This line of responsibility therefore remains confusing.

TTCs, however, are providing training opportunities for many teachers and are a critical part of rebuilding the education system in Afghanistan. Their weaknesses therefore need to be seen also in light of their strengths, and international organisations wishing to assist the TTCs should consider all aspects of the operation of the TTCs in their plan of support. It is also apparent that the most effective means of capacity building for the TTCs is the appointment of international qualified staff that work full-time at the TTC facility. On the job training, for areas including pedagogical technical support and administrative and financial support, through the appointment of qualified international staff at the TTC, is a means of following through with the new concepts and ideas learnt at various training programmes.

With regard to short-term teacher training programmes, one of the main lessons learnt from $A K D N$ is that often teachers work very hard to incorporate new concepts and ideas they learn from their training course into their every-day work - for a short time. Soon after, however, most teachers will revert back to their own known way of teaching. An example of how new methodologies taught as a part of the UNICEF Winter Teacher Training initiative have only partially been adopted is the concept of student "group work." A study conducted by SC/US of classrooms in the north of Afghanistan found that the concept of group work had caught on but only in part. Teachers were arranging their students into groups, and then continued a oneway dialogue of teaching in a rote learning fashion with the whole class. The UNICEF winter teacher training evaluation showed that the training of trainers approach maintained its integrity of training at each level. It was understood that the reason for this was the practical way in which the training was conducted, including specific exercises and practice groups. AKDN has found that teacher training programmes are most effective when based on the use of teaching materials. There remains, however, little information on the longer-term effects of the teacher training programmes that have been implemented in Afghanistan. 
The plans for the MoE to expand teacher training out of the urban TTC centres and into each of the districts throughout the country is an excellent initiative on behalf of the TTD. This type of concept moves beyond the infrastructure-based policies of the ministry in 2002 to 2003 into the qualitative needs of being a "good teacher." However, for this initiative to be successful, it is essential that the training, which head trainers from the TTD participate in, is well tested and is based on an expansive set of lessons already learnt from the field. This will ensure that teaching methodologies are indeed improved at the school level and the concept of teacher support teams is understood, as opposed to teacher inspection units.

Further to donor organisations, the lessons learnt particularly by NGO organisations can be a critical part of the development of the teacher training materials. Many of the NGOs have first hand experience of the difficulties and challenges of implementing an effective teacher training programme. In the past, the ministry has seen NGOs as competing with the MoE, rather than complimenting their work. However, there has been a clear move on behalf of the TTD over the past 12 months to recognise the valuable experiences of NGOs and to draw upon their expertise.

\section{LEARNING FROM EXPERIENCE}

\section{D.1 Learning from Afghanistan}

In Afghanistan, many teacher-training programmes are based on anecdotal evidence of poor teaching practices at the classroom level. Most teachers teach using rote learning methodologies. Teacher and student interaction is not common in classrooms and it is common practice for students to be punished for not doing well, ${ }^{22}$ rather than praised for their good work.

In 2004 Save the Children, US, as a part of the ADB-funded community-based education programme, conducted a week-long study of teaching methodologies at the school level in the northern part of Afghanistan. ${ }^{23}$ The finding of this study was that teacher training programmes need to remain very simple. Changing teaching methodologies is a challenge and their study recommends introducing one new concept to the teacher at a time, to give time for the teacher to master this new concept and then later for another new concept to be introduced. For example, in some of the classrooms studied, the students were unable to see the blackboard as they were sitting too far back in the classroom. In the whole year of teaching, the teacher did not notice this simple problem.

\section{* Observations of Teachers}

In most cases the teachers understood the concept of teaching but not the concept of learning. Teachers were often late to school, left during the middle of school time, or left the responsibilities of classroom activities to an older student, while the teachers were outside drinking tea. This is not the case of every teacher, however, the provincial education office teams that come to "inspect" schools only checked attendance records of teachers and students, ensured financial resources were properly allocated and that supplies received by the school were present. The Save the Children US study showed that most teachers did not prepare a plan for their teaching, although this is a requirement stipulated by the MoE Teacher Training Department in Kabul. ${ }^{24}$ In all classes observed the teacher remained the

\footnotetext{
22 Although there is no comprehensive study on this issue, violence in the classroom is widely reported. There are some reports of children being beaten so severely that they have had to be hospitalised with broken bones. In very few cases are the teachers reprimanded for such behaviour.

${ }^{23}$ Save the Children US, Planning Teacher Training in School in Two Districts of Faryab Province in Afghanistan, Mazar 2004.

${ }^{24}$ Ministry of Education, Policy of Teacher Standards, Afghanistan, 2004 (attached in Annex D)
} 
focal point of the lesson and children did repetitive tasks as a class, not individually. Below is an example of one class that was included in the study.

\section{Case study of a classroom - Dari language lesson}

The teacher read a sentence (copied onto the blackboard from the textbook) that used a particular letter from the Dari alphabet. The children repeated the sentence after her many, many times with children eventually shouting out the text. Many didn't even look at the book, or the blackboard. Then the teacher appointed a succession of children to read the sentence at the blackboard. The other children repeated the sentence after the child. Again, many children did not look at the book or the blackboard. The work at the blackboard lasted for just over 15 minutes. Finally, the children copied the sentence into their books until the lesson ended. The teacher watched the children and looked at a few of the books of the children on the front row but gave no comment. After the lesson the research team asked the teacher if the children could read the words in the sentence. She said yes. The team asked how she knew. She said she saw them read. (SCIUS 2004)

In many cases, if a child is asked to read a specific word in a sentence, he/she is unable to. Children are also often unable to write a single letter in a word. In most classes there are very few if no exercises or practice lessons. Lesson objectives are not clearly defined. Review of exercises is not done and teachers do not consider the individual learning needs of children. There is very little critical analysis of teaching approaches by the teachers themselves, believing what has been done in the past is the "right way" of teaching. Pedagogical capacity for teachers is often limited, however, subject knowledge is also limited. Many teachers have a detailed understanding of religion, but have a limited ability to teach academic or scientific subjects, such as history, geography, chemistry, physics or even language.

Further to this, many teachers do not feel any incentive to improve their method of teaching. They believe there is no reward system in place for teachers who are proactive and try new ideas in the classroom. Morale is low.

There is a lot of interest for teacher training programmes. From the SC/US report it seems that the main reason for this interest was to meet other teachers, to receive a per diem and to enjoy the lunch. Teacher training programmes therefore not only serve a purpose of improving teacher capacities, they also act to strengthen morale and give an opportunity to interact with fellow teachers in the region.

\begin{tabular}{|c|c|}
\hline \multicolumn{2}{|c|}{ Children's Perceptions on Quality Teaching } \\
\hline $\begin{array}{l}\text { A Good Teacher } \\
\text { - Is kind } \\
\text { - Teaches children to be } \\
\text { polite } \\
\text { - Teaches well } \\
\text { - Does not beat or insult } \\
\text { children } \\
\text { - Gives homework and } \\
\text { marks it } \\
\text { - Enters class with a } \\
\text { smiling face } \\
\text { - Has good manners } \\
\text { - Watches over all children } \\
\text { all the time }\end{array}$ & $\begin{array}{l}\text { A Bad Teacher } \\
\text { - Beats or insults children } \\
\text { - Does not teach } \\
\text { - Makes children stand on } \\
\text { one foot } \\
\text { - Leaves the class } \\
\text { - Enters class angry } \\
\text { - Writes the lesson on the } \\
\text { board and leaves the } \\
\text { class } \\
\text { - Is late }\end{array}$ \\
\hline
\end{tabular}

Source: Report Card, Human Rights Consortium

\section{* Observations of Students}

Despite many reports of violence against children in the classroom, the SC/US report observed little discipline and order in the classrooms. Often children would be disruptive in the classroom, late to a lesson, or leave early. Teacher expectations of the students were low. Poor performance of students was not considered the responsibility of the teacher, rather the fault of the student.

Many students were afraid of the teacher. There was little student/teacher interaction and in many cases, the teacher did not know the names of his or her students, even though the number of students in the classes included in the study was not excessively high. 
Student enrolment figures could also be misleading. Although there is a high rate of enrolment of students in Afghanistan compared to three years ago, the attendance of many of these students is very poor. ${ }^{25}$ Although there are many reasons for children not attending school regularly, the teaching ability of the teacher is a very important factor.

Language is another obstacle for learning in the classroom. There are two officially recognised languages by the MoE, Dari and Pashto. In some areas, particularly in the north, Uzbek is the mother tongue language of the children. The SC/US report indicates that this difficulty extend also to the teachers who often revert to their own mother tongue language, which in this case was Uzbek, even when teaching Dari or Pashto language classes. The new curriculum reform process undertaken with the MoE with the support of UNICEF and TCCU is trying to overcome this, with early primary school texts being developed in three languages: Dari, Pashto and Uzbek.

There have been a number of reports of discrimination by teachers and other students towards children from another ethnic group. The UNHCR Returnee Monitoring Report (2003-2004) ${ }^{26}$ shows that children returning to their village from a minority ethnic group can be victims of discrimination and even beatings at school.

\section{Community involvement in schools}

As in many post-conflict countries, the community networks and linkages have been either severely damaged or destroyed. Families therefore are preoccupied with rebuilding their own homes and reconstructing their own lives. They often do not expand their interests outside the household realm. This results in limited participation of parents and communities in improving the school environment for their children. Although education is highly valued in most communities in Afghanistan, it is often felt that it is solely the responsibility of the government to improve school environments and teacher capacities.

There is also a limited understanding by teachers themselves of the responsibility of the teacher to the community. Often teachers consider their responsibility to be limited only to those children in their classroom. Once they leave the classroom, they no longer have this responsibility for the children. Nor do many teachers feel a responsibility to students who are not attending school in the community where they teach. In some countries, such as Sri Lanka, teachers have taken the initiative to instigate a child-to-child methodology of bringing children in their own community into the school. Each child in the school was asked to find a friend that did not go to school and bring them to the class. In only one month these schools experienced an increase of 20 to $35 \%$ in student enrolment and attendance. ${ }^{27}$ In Afghanistan many lessons could also be learnt from projects such as CARE's COPE project, ${ }^{28}$ which aims to build community participation and inclusion in education for children.

There are a number of different internationally supported community development programmes being implemented in Afghanistan, including BRAC's girls' education programme and CARE's COPE Programme. The most comprehensive of these is the National

\footnotetext{
${ }^{25}$ A short interview with a child in the street in Kabul illustrates this point. When asked why the child did not go to school, the child responded that indeed they did go. The discussion continued with a member of the research team which revealed that the child had not gone to school for the whole year, but because they were officially "enrolled" in school the child believed this was the same as going to school.

${ }^{26}$ UNHCR, Returnee Monitoring Report 2003-2004, (unpublished document), Afghanistan, 2004

${ }^{27} \mathrm{UNICEF}$, Catch-up Education Response: Children Affected by Conflict. An Implementation Strategy. Sri Lanka, 2004

${ }^{28}$ CARE Afghanistan, Project Progress Report: Community Organised Primary Education (COPE)

Programme, Afghanistan, June 2004.
} 
Solidarity Programme (NSP), which is functioning in 19 provinces across the country and aims to develop a Community Development Council (CDC) in each village. The CDCs then decide on their own village priorities and implement a grant provided to them through the Ministry of Rural Rehabilitation and Development (MRRD). In many villages establishing a school in the village has been the priority.

\section{D.2 Learning from the Region}

A number of NGOs conducted teacher training for Afghan refugees in Pakistan and Iran for many years before the "return to Afghanistan" commenced in 2001/2002. IRC, Save the Children US, CARE, GTZ and Ockenden are among the major contributors to these programmes. During the $1990 \mathrm{~s}$, considerable research and evaluation of education programmes were undertaken, something which is currently lacking in the "emergency" environment of Afghanistan. The materials that were most commonly used in the refugee camps in Pakistan were the GTZ developed materials and the materials developed by the University of Nebraska at Omaha (UNO). Studies of home-based girls' schools in Pakistan showed that GTZ materials had been successful at supporting good learning results but were difficult to use for new teachers who had not undertaken extensive training. The UNO materials were weak and forced reliance on rote learning methods. Children depended too much on teacher direction. The weakest part of the programme was those areas of teaching that require explanation of concepts, independent learning and application of skills. The supervision and training of teachers focused on teacher behaviours rather than learning outcomes. $^{29}$

Further to some of the observations mentioned above in teacher training programmes, it was found in Afghan refugee communities that teacher training often placed an over emphasis upon teacher behaviours rather than student learning outcomes. There was often little understanding of how to pace teaching to learning needs of the students. In this respect, $\mathrm{SC} / \mathrm{US}$ recommended placing an emphasis on training in the use of instructional materials and developing knowledge of how to use them rather than attempts to increase the theoretical aspects of training. This finding is exactly what $A K D N$ found during the evaluation of training programmes of teachers in Afghanistan and matches the findings of the UNICEF supported Sindh Education Foundation recent study on teacher training programmes in southern Pakistan. ${ }^{30}$

\section{D.2.1 Basic Competency Learning (BCL) Materials}

In 2000 UNICEF and SC/US supported a large multi-agency Basic Competency Initiative. This initiative was founded from the idea that teachers needed to know what it was that they were teaching. This also gave the foundations of how to assess the competencies of teachers. In this programme a group of Afghan educators from around 20 agencies worked together to agree on basic competencies of Afghan children in maths and language from grades 1-6. The basic competencies are in a set of booklets for teachers and they describe what children should know and be able to do in maths and language at the end of each grade. They give a comprehensive and detailed outline of how teachers could improve the quality of their teaching in an Afghan context. From this set of competencies a more systematic teacher training programme started to be developed. The return to Afghanistan in 2001 disrupted this process. However, these basic competencies could still be used as a resource in Afghanistan to develop teacher training programmes while the official MoE curriculum is still being developed. This is a valuable set of materials that is rarely referred to in Afghanistan today.

\footnotetext{
${ }^{29}$ SCF/US, Home-based Girls' Schools in Bolochistan Refugee Villages: A Strategy Study, Pakistan, 2000

${ }^{30}$ Sindh Education Foundation, Review of Teacher Trainings for Primary Teachers in Balochistan, UNICEF Quetta, 2004.
} 
The competency-based concept extends beyond the competencies of the teachers. It also extends to understanding student competencies, or student learning achievements. A study conducted by SC/US in Balochistan in $2000^{31}$ recommends that teacher training programmes should not only focus on teacher competencies, but also assess the learning achievements of students. This ideology promotes the idea that if a student is learning, then the teacher must be teaching in a way that suits the students. A clear set of guidelines for "good" teachers is therefore not possible. Teachers should instead evaluate their performance on how well their students understand what they are being taught. Student learning achievements however cannot always be measured by how well they do in the exams the teacher sets. SC/US found that many teachers in fact always gave very good or good results for all students, rather than identifying where a student may be having difficulty and trying to overcome this.

The SC/US study showed that previous assumptions that home-based girls' schools were weaker schools because they evolved out of the non-formal education system and employ less "qualified" teachers were not grounded. This study, which focused on the interrelationship between teaching and learning, found that the learning achievements of the students in the home-based schools surpassed those in the formal schools in the refugee camps. Further to achieving

Home Based Schools for Afghan
Refugees in Pakistan
"There is a dedication and sense of
purpose in these (home-based)
schools that would be difficult to
exceed anywhere in the world."
Andrea Rugh, 2000
better results in home-based schools, only a very few number of students failed. In the Pashto test, $60 \%$ of the home-based school students passed the test, and only $3 \%$ received a grade lower than $40 \%$. This is dramatically different from students in the formal schools in the refugee camps with a $28 \%$ pass rate and $25 \%$ who got less than $40 \%$ of the questions correct. All students were in grades 1-6. Once students started studying subjects at a higher grade, often the teachers did not have the specific subject knowledge needed to teach the students. Most of the teachers in the home-based schools were women, often with schooling that did not surpass grade 6. It was found, therefore, that teacher academic qualifications and backgrounds did not affect student learning, particularly in the earlier grades. The study found that teachers with the highest academic qualifications had lower than average test scores than did teachers who completed less than grade 12 .

\section{D.2.2 Returning Afghan Teachers from the Region}

Specific mention will be made here of the GTZ supported BEFAR (Basic Education for Afghan Refugees) programme in the northwest frontier of Pakistan, the Ockenden teacher training for returning refugees in Iran and the United Nations High Commissioner for Refugees (UNHCR) returnee monitoring system.

The BEFAR programme is the largest non-formal education programme globally and has been operating for more than 15 years. During this time they have developed teacher training materials and student text books through a process of continuous evaluations and lessons learnt for the educational needs of Afghan communities in more remote areas. Much of the student materials were adopted and included in the UNICEF supported women's literacy materials for Afghanistan, which were developed in 2002/2003 (yet to be printed). The Department of Literacy within the MoE has made formal requests for BEFAR staff to come to Afghanistan and provide technical assistance on non-formal education teacher training both in Kabul and in the provinces. No funds are yet available for this activity. The BEFAR teachers, many of who are Afghan and have been involved in the teacher training programmes for many years, have also expressed an interest in returning to Afghanistan. BEFAR has developed a detailed database of approximately 5,000 Afghan teachers who were willing to

\footnotetext{
${ }^{31}$ Andrea Rugh \& John Gillies, Baseline Study of Teaching-Learning in SC/US Afghan Refugee Schools of Balochistan, Academy for Educational Development, Pakistan, 2000.
} 
return if they could secure a teaching position with the MoE. This database has been made available to the MoE, UNHCR and the United Nations Development Programme (UNDP).

The Ockenden teacher training programme for returning Afghan refugees in Iran has also developed a database of Afghan teachers willing to return. ${ }^{32}$ This database consists of 1,000 trained Afghan teachers. Although it has not been shared with the MoE to date, this information is readily available if the $\mathrm{MoE}$ wishes to review it.

The accreditation of returning qualified Afghan teachers particularly from neighbouring countries, remains a complicated and bureaucratic process. UNHCR has the records of many thousands of people who are qualified teachers and who wish to return to Afghanistan. However, during UNHCR's returnee monitoring activities in Afghanistan, ${ }^{33}$ it was found that many teachers, approximately 9 out of 10 , do not go through the difficult and costly procedure of being "accredited" by the MoE so they may seek employment as a teacher. At present a person who wishes to have their qualifications accredited by the MoE must first have their documents stamped and approved by the Afghan Consulate in their country of asylum. For many Afghans, movement throughout their country of origin is difficult and costly. After their return to Afghanistan, they should then travel to Kabul to have their documents stamped by the central MoE. In many cases, teachers are not being accredited because they do not have suitable documents.

\section{Analysis Section D}

Lessons learnt at the classroom level are critical when developing and designing teacher training programmes. At present in Afghanistan, there is very little research and analysis of programmes that are working and programmes that are not working. Both are equally important in understanding what programmes to build upon.

In 2001 there was some controversy over the use of the basic competency learning (BCL) materials. For a range of reasons the materials were not adopted by the MoE in Afghanistan, however, in an evaluation of their use in Afghanistan during $2002,{ }^{34}$ it was found that in areas where the teachers' own competencies were stronger, the BCL materials were well received (such as in Kabul and Mazar). However, there was a great reluctance for teachers in other parts of Afghanistan, especially in the southern and eastern regions, to use these books. The BCL books did not focus on rote learning. There were many exercises in these books and they created a lot more work for teachers. Therefore, in some areas teachers preferred to use the current textbooks developed in the 1980 s by UNO, as these books used constant repetition as a key learning tool.

It can therefore not be assumed that once new teaching materials and textbooks are developed that teachers will automatically welcome them. The study of the use of the GTZ materials in the northwest frontier of Pakistan also supports this, as they show that teachers without extensive training on the use of the materials often find difficulty in using them. There are plans for the TTD in the MoE to link more closely with the Department of Compilation and Translation (curriculum development department). However, there may need to be a comprehensive teacher training plan for the use of the new curriculum of Afghanistan. Some organisations have suggested that the rapid in-service teacher training programme, planned for the end of 2004, could be postponed until the end of 2005, and linked to the use of the new children's textbooks. This would also allow time for a more effective study and evaluation of previous and current teacher training programmes.

\footnotetext{
${ }^{32}$ Discussion with Ockenden Regional Director, Kabul, 2004

${ }^{33}$ UNHCR, Returnee Monitoring Report 2003-2004, Afghanistan 2004

${ }^{34}$ UNICEF, Field Report, Kandahar, Kabul, Mazar, 2001.
} 
Teacher competencies remain to be another issue. The ministry continues to place a great deal of emphasis on the "qualifications" of teachers. As was found from the SC/US study in Balochistan, teachers may not need to have such qualifications and in fact their teaching ability was shown to be much better than the teachers in the formal schools. The way in which this assessment was conducted highlights an issue that may also need to be considered in Afghanistan. The evaluation assessment took the learning achievements of students to be the basis on which they assessed the ability of the teacher. They did not develop a set of "teacher standards" and then assess the teacher solely on this basis. These recommendations and findings are directly relevant to the learning and teaching environment of Afghanistan, where almost all teacher development programmes have focused entirely on the assessment of teacher requirements and standards. Most recently in Kabul as a part of a workshop to develop teacher standards it was stated "If we don't have standards or descriptions of good teaching in the classroom how do we know if a teacher is good or bad? If we don't have standards that is an agreed upon description of good teaching, how do we decide what to teach teachers?" 35

The SC/US study found that there was too little focus in the entire schooling systems on what children should be learning, and too much focus on prescribed teacher behaviours; insufficient teacher understanding of the effects of their teaching practices on learning; and a lack of awareness of the range of options to help students become confident, independent learners. The study recommended: developing a system for continuous assessment of learning; developing teacher supports to increase learning; and developing a better system for teacher selection. Further to this study, learning at the classroom level can also be affected by teacher and student prejudices. A more effective system of monitoring continual student learning achievements could work towards overcoming some of these issues.

In this section, again, the issue of teacher deployment is raised. There is a great resource of qualified Afghan teachers in Iran and Pakistan. A systematic method of encouraging their return and supporting them in seeking employment in Afghanistan may also assist the $\mathrm{MoE}$ with its severe shortage of teachers. The present system needs to be simplified so that it becomes an incentive for teachers to return, rather than acting as a deterrent, as currently is the case. Drawing upon the resources of organisations such as GTZ and Ockenden, as well as a closer integration with the information available through UNHCR, could assist the MoE in partially realising its goals of recruiting a further 38,000 teachers.

\section{E. CONCLUSIONS AND RECOMMENDATIONS}

The education sector in Afghanistan has seen some significant improvements in the past two and half years, much of this is the credit of the $\mathrm{MoE}$, MoHE, supporting international organisations and the overwhelming desire for the children of Afghanistan to go back to school. Much of the education programmes to date have been the result of an "emergency" environment. With almost no educational opportunities available to a large proportion of the Afghan population, the massive return of so many Afghans to their home country, and the destroyed physical and administrative education structure in the country, the task at hand in 2001-2002 was overwhelming. There remains a serious shortage of schools, teachers, teacher training institutes and teaching materials. However, the situation in Afghanistan is now moving through a transitional phase, from emergency to post-conflict reconstruction and development. Educational programmes and policies therefore need to change in accordance with this.

\footnotetext{
${ }^{35}$ MoE, Status Report: The New Primary School Teacher Education Curriculum for Afghanistan, Kabul, Afghanistan, 2004.
} 
As a result of this study, three major recommendations are being made. The first is in relation to the integration of the formal schools and home-based schools. The second suggests an expansion of qualitative research and evaluation and the third recommends the development of a detailed teacher education and professional development plan, based on the results of the EMIS and population statistics.

\section{- Integration of formal schools and home-based schools}

To improve the allocation of teachers, especially in the rural areas, it might be wise to have the Ministry and some organisations to strengthen the linkages between the teachers of the home-based schools and the formal schools. The recruitment of an additional 38,000 teachers into the primary education system could be partially realised through the systematic incorporation of home-based teachers. The $\mathrm{MoE}$ may consider the expansion of its responsibilities beyond the school boundaries because as shown in the SC/US report ${ }^{36}$ the teaching competencies of home-based school teachers at the primary school level are often higher than the teachers with officially recognised teacher qualifications. Given that the greatest shortage is in women teachers in the rural areas at primary school level, home-based schools could be considered within the broader framework of the MoE policies and strategies. The total number of home-based schools still operating in Afghanistan is not known. Most include classes of only 5-10 students who are normally girls. The home-based schools are normally taught by a relative and follow the same curriculum as the formal schools. Because most of these home-based schools exist in someone's house and may include only a few female members of the community, they often do not consider themselves a "school." At present teacher training programmes of the $\mathrm{MoE}$ are only available to MoE staff. If these types of teachers could include in their classes several more students, and could themselves be included in some of the teacher training programmes offered to MoE teachers, the expansion of teachers at the primary school level may be partially realised. Programmes that are already being developed along these lines are the BRAC, CARE and ADB programmes. They focus on linking the educational needs of children into a community development model. In this forum, educational programmes may have the opportunity to expand their horizons to other community development programmes, such as the National Solidarity Programme (NSP), where many of the villages are prioritising the establishment of schools.

\section{- Research and Evaluation}

In the "emergency" environment of Afghanistan, qualitative research and evaluation of teacher training programmes as well as the education sector generally has been very limited. There is a strong move at present on behalf of the MoE and supporting organisations to provide large-scale teacher training programmes. These will assist the ministry to ensure that all teachers of Afghanistan can be included in some form of training. However, the training could be significantly improved if it was based on concrete evaluations and lessons learnt from other teacher training programmes. Most teacher training activities conduct a short-term assessment of the implementation of the training, but there are few studies on how the training has affected the student learning achievements in the longer-term. A more detailed study of student learning achievements could be initiated and from this, a better understanding of how students learn and what teachers might already be doing to assist this learning process would be understood.

There are also limited studies available in Afghanistan of parental attitudes to education. UNICEF has conducted a large-scale study on girls' education in Afghanistan. ${ }^{37}$ However, further studies could be conducted of perceptions of how education is valued, in different ethnic groups, in different geographic areas and of families with different socio-economic

\footnotetext{
${ }^{36}$ Andrea Rugh, John Gillies, Baseline Study of Teaching-Learning in SC/US Afghan Refugee Schools of Balochistan, Academy for Educational Development, Pakistan, 2000.

${ }^{37}$ UNICEF, Communication Strategy, Towards Behaviour Change for Girls Education (Draft), Afghanistan, June 2004.
} 
backgrounds. This should also include what is understood as meaning "education." Linked to student learning achievements, there are anecdotal reports from across the country of discrimination of teachers towards children of different ethnic, religious and socio-economic backgrounds. In addition, there is limited information of whether, in a post-conflict environment such as Afghanistan, teachers are advocating ideals of peace and co-existence or reinforcing social divisions and an environment of intolerance. Research on this topic could then be fed into the human rights cell in the MoE, so the findings can be further incorporated into education planning and teacher training programmes.

Three key areas are, therefore, recommended for further research. These include: a study of student learning achievements and teacher competencies; a long-term assessment and evaluation of teacher training programmes that have already been implemented in Afghanistan; and a more comprehensive study of community attitudes to education and how they define "education." Included in this final recommendation might be a further investigation of how education may be promoting an environment of peace and tolerance or reinforcing social and cultural divisions.

\section{- Policy Document for Teacher Training}

At present information on the number and location of teachers is unreliable. From the data provided to the AREU research team from the Department of Planning at the MoE, the appriopriate allocation of teachers appears to be the main problem, with a chronic shortage of primary school teachers in most provinces across the country, and possibly too many teachers at the upper-secondary school level. The availability of female teachers, particularly in the south and southeast of the country, remains a problem.

This information, however, needs to be assessed in the light of the country's population statistics. Population statistics from $2002^{38}$ highlight areas where, as a percentage of the total population, there are insufficient teachers. At this stage, with the currently unreliable data available from the MoE, an analysis of population to teacher and student figures would not yield the information required. Instead, once the EMIS data is available, a more thorough analysis will be necessary and possible.

Once the results of the EMIS have been collated and analysed, together with population statistics, a better picture will be available of the real needs in teacher deployment and training. From this information, a more detailed policy document could be developed with the TTD and supporting organisations, including the TEP members, which would include a province-by-province plan. It should incorporate the national plan of TRCs, but also be more specific in those provinces such as Kandahar for primary education and Nooristan in secondary education, of what could be done to improve the number of teachers.

As a result of the work of TEP, a more coordinated approach to teacher training has been developed. Discussions continue about the best way to move forward for teacher development and some concrete recommendations have resulted from this. However, a detailed policy document of teacher professional development and deployment is not available. This type of document would be invaluable for the future direction of the MoE, the MoHE and all organisations supporting teacher education and professional development in Afghanistan.

\footnotetext{
${ }^{38}$ Government of Afghanistan, CSC 2003-2004 Population Statistics 388 Districts, Afghanistan 2004. (This information was developed in preparation for the elections, it is understood that these figures may also not be 100 percent reliable, however, they can be a base set of data to work from).
} 


\section{SELECT REFERENCES}

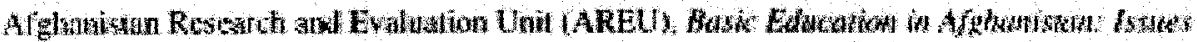

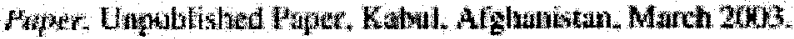

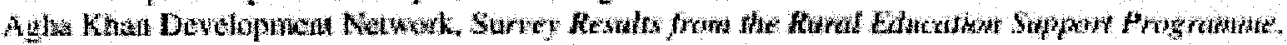

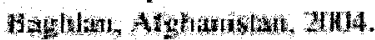

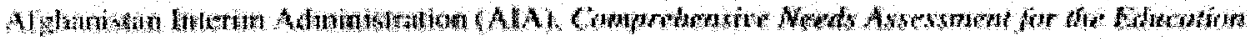

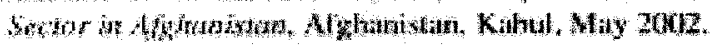

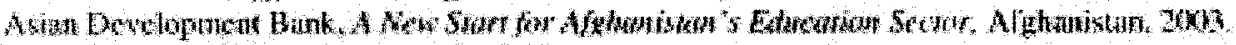

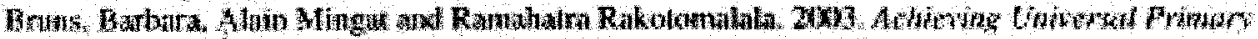

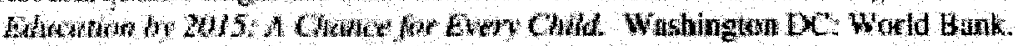

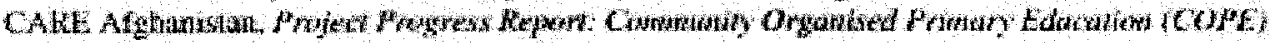

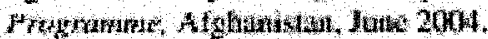

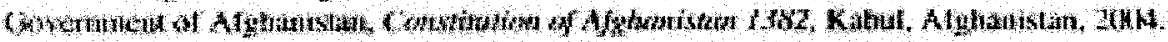

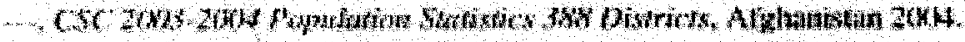

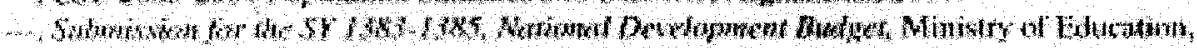

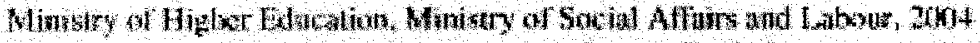

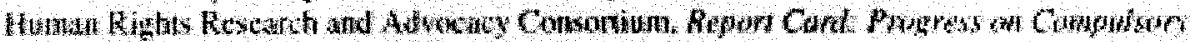

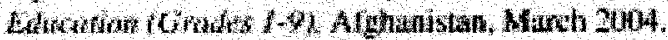

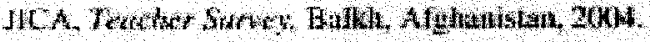

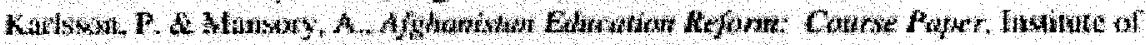

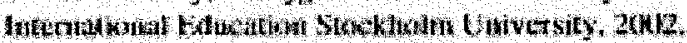

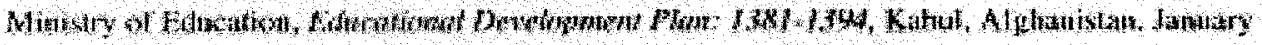
ZWW

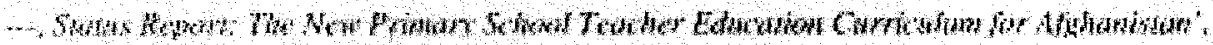
Kutw1, Arghanistun, $20 \%$.

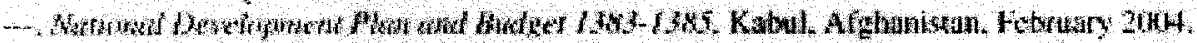

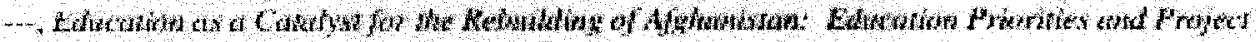
Frofth. Alghoisco, March 204.

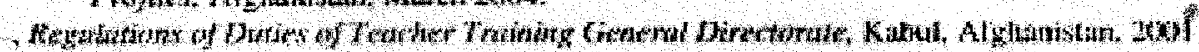

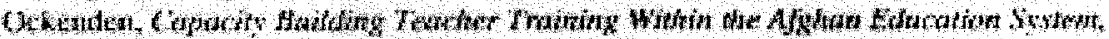

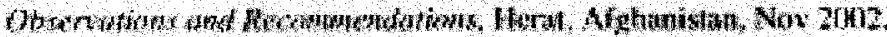

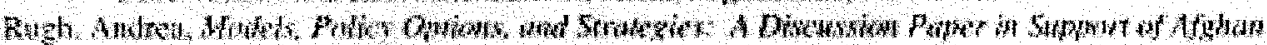
Ellaran Paksukn, 001 .

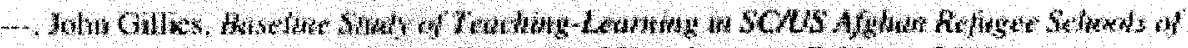

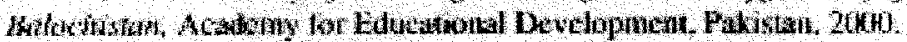

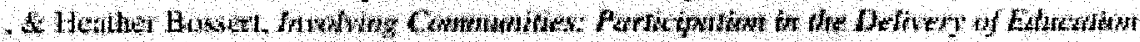

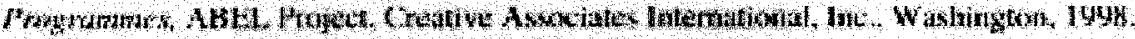

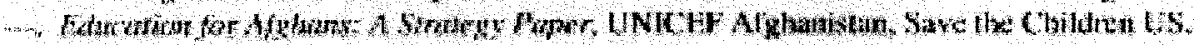
Pakistan. 1908

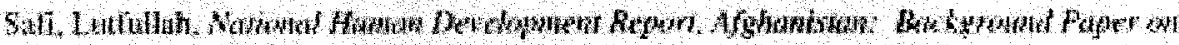

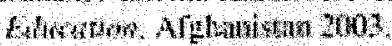

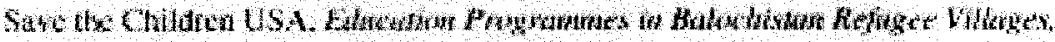
Pakistow delantstan Fidd Onke, $20 \mathrm{~km}$.

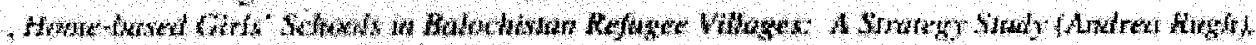
Pakistan, Jivi:

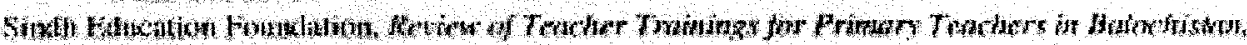
WNCEF MUeri, 20144

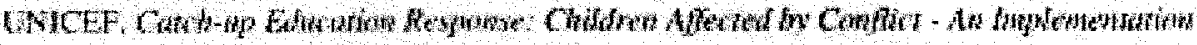
Srowne si Lunk, 20u4

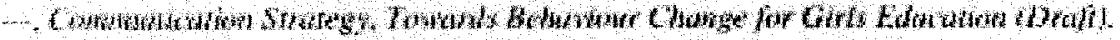
Mghanum, Jow 2114 .

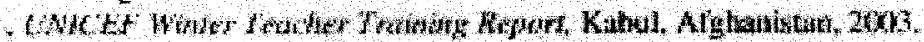

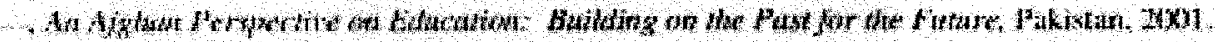

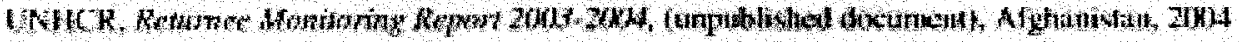

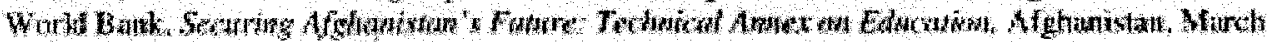
2004 


\section{Annex A: Teacher and Student Figures}

\begin{tabular}{|c|c|c|c|c|c|c|c|c|c|}
\hline \multicolumn{10}{|c|}{ PFMARY SOHOOL STATISTICS } \\
\hline \multirow[b]{2}{*}{$\mathrm{No}$} & \multirow[b]{2}{*}{ Prownces } & \multicolumn{2}{|c|}{ Number of Sudents. } & \multirow{2}{*}{$\begin{array}{l}\text { Total number of } \\
\text { students }\end{array}$} & \multicolumn{2}{|c|}{$\begin{array}{c}\text { Number of leachess } n \\
\text { primary schods }\end{array}$} & \multirow{2}{*}{$\begin{array}{l}\text { Total Nanber } \\
\text { of Teaders }\end{array}$} & \multirow{2}{*}{$\begin{array}{l}\text { Nomber of } \\
\text { Pmery } \\
\text { Satoots }\end{array}$} & \multirow{2}{*}{$\begin{array}{c}\text { Sudents } \\
\text { Toachess Ratho }\end{array}$} \\
\hline & & Male & Fenale & & Nave & Female & & & \\
\hline 1 & Kaou & 38,553 & 30,120 & 68,673 & 1,012 & 173 & 1,185 & 76 & 58 \\
\hline 2 & Kavisa & 49,922 & 9834 & 59,756 & 913 & 138 & 1,051 & 76 & 57 \\
\hline 3 & Parwan & 121,597 & 91,333 & 212930 & 1,311 & 188 & 1,499 & 168 & 142 \\
\hline 4 & Wardak & 58,865 & 38,718 & 97,583 & 1,143 & 135 & 1,278 & 156 & 76 \\
\hline 5 & Logar & 42611 & 11,791 & 54,402 & 750 & 169 & 919 & 105 & 59 \\
\hline 6 & Ghaze: & 82,659 & 32,959 & 115,618 & 1,085 & 265 & 1,350 & 180 & 86 \\
\hline 7 & Pakta : & 51,755 & 12968 & 64720 & 1297 & 134 & 1,431 & 109 & 45 \\
\hline 8 & Wagahar & 173,645 & 90,476 & 264,121 & 2531 & 369 & 2,920 & 183 & 90 \\
\hline 9 & Laghman & 42456 & 22713 & 65,169 & 915 & 42 & 1,057 & 78 & 62 \\
\hline 101 & Konar & 36,853 & 15,341 & 52,234 & 1,170 & 81 & 1,351 & 184 & 39 \\
\hline 11 & Eadakhstan & 94,226 & 65,99 & 160,025 & 1278 & 20 & 1,573 & 207 & 102 \\
\hline 12 & Takha & 73,905 & 37,142 & 11,047 & 2367 & 190 & 2,557 & 158 & 43 \\
\hline 13 & Baghan & 79,559 & 27300 & 106,892 & 1,531 & 143 & 1,674 & 134 & 64 \\
\hline 14 & Kunduz & 96,351 & 51,837 & 148,188 & 1,693 & 70 & 1,763 & 173 & 84 \\
\hline 15 & Samargan & 17862 & 7,453 & 25315 & 312 & 47 & 359 & 127 & 71 \\
\hline 16 & Balkh & 150,066 & 113046 & 263,112 & 2280 & 748 & 2,978 & 290 & 88 \\
\hline 17 & Jawzian & 86,491 & 57640 & 144131 & 880 & 436 & 3316 & 117 & 110 \\
\hline 18 & Fayab & 47,836 & 20,365 & 68,201 & 1,417 & 569 & 1986 & 234 & 34 \\
\hline 19 & Baoghis & 23450 & 5167 & 28,626 & 724 & 32 & 756 & 135 & 38 \\
\hline 20 & Herat & 190,487 & 140,769 & 331256 & 3,413 & 866 & 4,379 & 268 & 76 \\
\hline 21 & Garah & 28736 & 9707 & 30,443 & 884 & 132 & 1,016 & 156 & 38 \\
\hline 22 & Nontoz & 2760 & 6275 & 19005 & 379 & 178 & 557 & 51 & 34 \\
\hline 23 & Helinard & 63,541 & 3755 & 67,299 & 1642 & 43 & 1,685 & 158 & 40 \\
\hline 24 & Kardatrar. & 287,001 & 34841 & 321842 & 1512 & 27 & 1739 & 200 & 185 \\
\hline 25 & Zaou & 14513 & 518 & 15,031 & 612 & 27 & 60 & 125 & 24 \\
\hline 26 & Untrgan & 14,09 & 2688 & 17,397 & 782 & 96 & 878 & 171 & 20 \\
\hline 27 & Shor & 64,302 & 6,424 & 70,726 & 2366 & 68 & 2,456 & 250 & 29 \\
\hline 28 & Bamyan & 42956 & 9813 & 52769 & 500 & 162 & 682 & 134 & 77 \\
\hline 29 & Paktika & 38,026 & 4,013 & 42039 & 162 & 187 & 1815 & 22 & 23 \\
\hline 30 & Saroul & 33662 & 8,042 & 41,704 & 1333 & 150 & 1483 & 445 & 28 \\
\hline 31 & Goost & 69,760 & 5640 & 75,400 & 1,296 & 9 & 1,304 & 106 & 58 \\
\hline 32 & Nooristan & 29,061 & 10,008 & 39369 & 920 & 35 & 958 & 64 & 41 \\
\hline & Ketou oy & 208,229 & 344073 & 522302 & 310 & 4044 & 4,354 & 7 & 120 \\
\hline Totalo & of Prownes: & $2,258,318$ & 984795 & $3,246,113$ & 41,850 & 6,744 & 48,504 & 5,250 & 67 \\
\hline Grand & Total & $2,466,547$ & 1290,068 & $3,766,415$ & 42160 & 10,78 & 52,948 & 5.257 & 7 \\
\hline
\end{tabular}




\section{Annex A: Teacher and Student Figures}

\begin{tabular}{|c|c|c|c|c|c|c|c|c|c|}
\hline \multicolumn{10}{|c|}{ PRIMARY SCHOOL STATISTICS } \\
\hline \multirow[b]{2}{*}{ W. } & \multirow[b]{2}{*}{ Prowinces } & \multicolumn{2}{|c|}{ Number of Students. } & \multirow{2}{*}{$\begin{array}{l}\text { Total number of } \\
\text { students }\end{array}$} & \multicolumn{2}{|c|}{$\begin{array}{c}\text { Nimber of teachers in } \\
\text { puimay schools }\end{array}$} & \multirow{2}{*}{$\begin{array}{l}\text { Total Number } \\
\text { of Teacters }\end{array}$} & \multirow{2}{*}{$\begin{array}{l}\text { Number of } \\
\text { Brimay } \\
\text { Sctoods }\end{array}$} & \multirow{2}{*}{$\begin{array}{l}\text { Sudents } \\
\text { Teathers Fatio }\end{array}$} \\
\hline & & Mate & Fonale & & Mule & Fanale & & & \\
\hline & Kabul & 38,553 & 30,120 & 68,673 & 1,012 & 173 & 1,185 & 76 & 58 \\
\hline & Kapisa & 49,922 & 9,834 & 59756 & 913 & 138 & 1,051 & 76 & 57 \\
\hline 38 & Parwan & 121,597 & 91,338 & 212900 & 1,311 & 188 & 1,499 & 168 & 142 \\
\hline & Wardak & 58,865 & 38,718 & 97583 & 1,143 & 135 & 1,278 & 156 & 76 \\
\hline 51 & Logar & 42611 & 11,791 & 54,402 & 750 & 169 & 919 & 105 & 59 \\
\hline 6) & Ghazh: & 82,659 & 32,959 & 115,618 & 1,085 & 265 & 1,350 & 180 & 86 \\
\hline 71 & Palta & 51,755 & 12,965 & 64720 & 1,297 & 134 & 1,431 & 109 & 45 \\
\hline 81 & Nagahar & 173,645 & 90,476 & 264,121 & 2531 & 389 & 2,920 & 163 & 90 \\
\hline 9 & Laghrian & 42,456 & 22713 & 65,169 & 915 & 142 & 1,057 & 78 & 62 \\
\hline 101 & Funat & 36,953 & 15,341 & 52294 & 1,170 & 181 & 1,351 & 184 & 39 \\
\hline 11 & Boddolnshan & 94,226 & 65799 & 160,025 & 3278 & 295 & 1.573 & 207 & 102 \\
\hline 12 & Talhar & 70,905 & 37,142 & 111,047 & 2367 & 190 & 2,557 & 158 & 43 \\
\hline 131 & Baghat & 79,589 & 27303 & 106,892 & 1531 & 143 & 1674 & 134 & 64 \\
\hline 14 & Kundz & 96,351 & 51,337 & 148,188 & 1,693 & 70 & 1,763 & 173 & 84 \\
\hline 151 & Samangan & 17,862 & 7453 & 25315 & 312 & 47 & 359 & 127 & 71 \\
\hline 16 & $\mathrm{Balkh}$ & 150,066 & 113,046 & 263,112 & 2230 & 748 & 2978 & 293 & 88 \\
\hline 17 & Jawzjan & 86,691 & 57,640 & 144,131 & 880 & 436 & 1,316 & 177 & 110 \\
\hline 18 & Faryal & 47836 & 20,365 & 68201 & 1,417 & 569 & 1,986 & 234 & 34 \\
\hline 19 & Dadghis & 23,459 & 5167 & 28,626 & 724 & 32 & 756 & 135 & 38 \\
\hline 201 & Herat & 190,487 & 140769 & 331,256 & 3413 & 966 & 4,379 & 268 & 76 \\
\hline 21 & Farah & 28,36 & 9707 & 38,443 & 884 & 132 & 1,016 & 158 & 38 \\
\hline 22 & Ninroz & 12,760 & 6275 & 19,035 & 379 & 18 & 567 & 51 & 34 \\
\hline 231 & Holmand & 63,544 & 3756 & 67299 & 1,642 & 49 & 1,685 & 158 & 40 \\
\hline 24 & Kandahar & 287,001 & 34,841 & 321,842 & 1,512 & 22 & 1739 & 200 & 185 \\
\hline 25 & Zabul & 14513 & 518 & 15,031 & 612 & 27 & 60 & 125 & 24 \\
\hline 26 & Lruzgan & 14,709 & 2680 & 17,397 & 782 & 96 & 878 & 171 & 20 \\
\hline 27 & Gho: & 64,302 & 6424 & 70,726 & 2368 & 88 & 2,456 & 250 & 29 \\
\hline 28 & Benyan & 42956 & 9,813 & 52769 & 520 & 162 & 68 & 134 & 77 \\
\hline 29 & Palktka & 38,026 & 4013 & 42,039 & 1628 & 187 & 1,815 & 227 & 23 \\
\hline 30 & Sarpol & 33,662 & 8042 & 41,704 & 133 & 150 & 1,483 & 445 & 28 \\
\hline 31 & Whast & 69,700 & 5640 & 75,400 & 1235 & 9 & 1,304 & 106 & 56 \\
\hline 32 & Nooristan & 29,061 & 10308 & 39,369 & 923 & 35 & 958 & 64 & 41 \\
\hline & Kavol Cly. & 208229 & 314,073 & 522,302 & 310 & 4,049 & 4354 & 7 & 120 \\
\hline Totalo & of Prownos & $2,258,318$ & 984796 & $3,243,113$ & 41850 & 6,744 & 48,594 & 5,250 & 67 \\
\hline Grand & Tota & $2,466,547$ & $1,298,868$ & 3765,415 & 42160 & 1078 & 52948 & 5257 & 71 \\
\hline
\end{tabular}




\begin{tabular}{|c|c|c|c|c|c|c|c|c|c|}
\hline \multirow[b]{2}{*}{ No } & \multirow{2}{*}{ Prownces } & \multicolumn{2}{|c|}{ Ninber of Sudents } & \multirow{2}{*}{$\begin{array}{l}\text { Tolal number of } \\
\text { students }\end{array}$} & \multicolumn{2}{|c|}{$\begin{array}{c}\text { Murtber of teachers in innot } \\
\text { seconday sconols }\end{array}$} & \multirow{2}{*}{$\begin{array}{l}\text { Total Wumber: } \\
\text { of Teachers }\end{array}$} & \multirow{2}{*}{$\begin{array}{l}\text { Number of Junio: } \\
\text { Secondary Sctiools }\end{array}$} & \multirow{2}{*}{$\begin{array}{l}\text { Sudents } \\
\text { Teachers Ratio }\end{array}$} \\
\hline & & Male & Female & & Nole & Fornde & & & \\
\hline 1 & Kabul & 3,268 & 3,015 & 6,283 & 251 & 75 & 328 & 45 & 19 \\
\hline 2 & Kapisa & 7.455 & 607 & 8,062 & 452 & 29 & 481 & 34 & 17 \\
\hline 3 & Parwan & 12817 & 562 & 13,379 & 1,082 & 75 & 1,107 & 103 & 12 \\
\hline 4 & Wardak & 5,554 & 5 & 5,559 & 395 & 42 & 437 & 25 & 13 \\
\hline 5 & Logar & 5,366 & 133 & 5,499 & 351 & 115 & 46 & 26 & 12 \\
\hline 6 & Ghazh & 7,711 & 2,100 & 9811 & 594 & 228 & 822 & 78 & 12 \\
\hline 7 & Paktia & 13,209 & 258 & 13,467 & 311 & 46 & 35 & 20 & 38 \\
\hline 8 & Nagana & 13,84 & 1245 & 15,086 & 662 & 21 & 683 & 53 & 22 \\
\hline 9 & Lagmman & 5,009 & 69 & 5,078 & 332 & 70 & 402 & 15 & 13. \\
\hline 10 & Kunar & 2809 & 143 & 2952 & 166 & 4 & 170 & 17 & 17 \\
\hline 11 & Badakhathan & 8,559 & 3672 & 12,231 & 146 & 274 & 420 & 119 & 20 \\
\hline 12 & Takhar & 6,973 & 1859 & 8,822 & 1,043 & 149 & 1,192 & 40 & 7 \\
\hline 13 & Bogrtan & 8,387 & 1,791 & 10,178 & 1398 & 162 & 1,560 & 5 & 7 \\
\hline 14 & Kunduz & 4,764 & 819 & 5583 & 559 & 167 & 76 & 14 & 8 \\
\hline 15 & Samancan & 2,100 & 317 & 2,417 & 210 & 78 & 296 & 38 & 8 \\
\hline 16 & $\mathrm{Ba}$ & 9,845 & 5,831 & 15,676 & 800 & 70 & 1,518 & 32 & 10 \\
\hline 17 & Wagkan & 12,247 & 6785 & 19032 & 902 & 330 & 1,232 & 38 & 15 \\
\hline 18 & Eanab & 2704 & 974 & 3,676 & 251 & 181 & 432 & 19 & 9 \\
\hline 19 & Bodgiss & 1,238 & 114 & 1,362 & 133 & 5 & 136 & 5 & 10 \\
\hline 20 & Herat & 12,131 & 6,507 & $1860^{2} 8$ & 799 & 456 & 1,105 & 62 & 16 \\
\hline 21 & Farah & 1726 & 91 & 1817 & 160 & 73 & 233 & 17 & 8 \\
\hline 22 & Nmoz & 545 & 154 & 698 & 76 & 38 & 104 & 1 & 7 \\
\hline 23 & Helmend & 2237 & 92 & 2329 & 709 & 31 & 740 & 30 & 3 \\
\hline 24 & Kandahar & 2010 & 62 & 2,072 & 676 & 101 & 77 & 59 & 8 \\
\hline 25 & Zabul & 372 & -3 & 372 & 211 & 10 & 221 & 5 & 2 \\
\hline 26 & Urwogar & 37 & 37 & 408 & 232 & 73 & 305 & 19 & 1 \\
\hline 27 & Ghor & 4,595 & 65 & 4,660 & 123 & 12 & 135 & 9 & 3 \\
\hline 28 & Banyar: & 605 & 437 & 1042 & 574 & 58 & 632 & 20 & 2 \\
\hline 29 & Paktika & 1,025 & + & 1,025 & 404 & 54 & 458 & 21 & 2 \\
\hline 30 & Sarou & 681 & 128 & 809 & 193 & 56 & 249 & 13 & 3 \\
\hline 31 & Krost & 4,775 & 2 & 4775 & 70 & 3 & 70 & 15 & 68 \\
\hline 32 & Nooristan & 4,195 & 595 & 4,730 & 60 & + & 60 & 13 & 79 \\
\hline & Kabul city & 53,151 & 20,619 & 82,70 & 1,480 & 2984 & 4.467 & 81 & 19 \\
\hline Total & of Provinces & 169,064 & 38,467 & 207,531 & 14223 & 3,721 & 17,944 & 1,062 & 12 \\
\hline Frand & Total & 222215 & 68,086 & 290,301 & 15,706 & 670 & 22,411 & 1,143 & 13 \\
\hline
\end{tabular}




\begin{tabular}{|c|c|c|c|c|c|c|c|c|c|}
\hline \multicolumn{10}{|c|}{ UPPER SECONDARY SCHOOL STATISTICS } \\
\hline \multirow[b]{2}{*}{ No } & \multirow[b]{2}{*}{ Provinces } & \multicolumn{2}{|c|}{ Number of Studients } & \multirow{2}{*}{$\begin{array}{l}\text { Total number of } \\
\text { students }\end{array}$} & \multicolumn{2}{|c|}{$\begin{array}{c}\text { Number of teachers in upper } \\
\text { secondary schools }\end{array}$} & \multirow{2}{*}{$\begin{array}{l}\text { Total Number } \\
\text { of Teachers }\end{array}$} & \multirow{2}{*}{$\begin{array}{l}\text { Number of } \\
\text { Schoois }\end{array}$} & \multirow{2}{*}{$\begin{array}{c}\text { Students/ } \\
\text { Teachers Ratio }\end{array}$} \\
\hline & & Male & Female & & Male & Female & & & \\
\hline 1 & Kabul & 2,113 & 798 & 2,911 & 212 & 43 & 255 & 33 & 11 \\
\hline 2 & Kapisa & 3,505 & 83 & 3,588 & 207 & 27 & 234 & 22 & 15 \\
\hline 3 & Pawan & 4,506 & 34 & 4,540 & 882 & 79 & 961 & 54 & 5 \\
\hline 4 & Wardak & 2,226 & - & 2,226 & 605 & 44 & 649 & 29 & 3 \\
\hline 5 & Logar & 1,725 & - & 1,725 & 402 & 32 & 434 & 16 & 4 \\
\hline 6 & Ghazni & 2,435 & 529 & 2,964 & 693 & 297 & 990 & 74 & 3 \\
\hline 7 & Paktia & 2,941 & 15 & 2,956 & 101 & 27 & 128 & 20 & 23 \\
\hline 8 & Nagahar & 6,289 & 412 & 6,701 & 354 & 25 & 379 & 51 & 18 \\
\hline 9 & Laghman & 1,595 & - & 1,595 & 330 & - & 330 & 17 & 5 \\
\hline 10 & Kunar & 1,286 & - & 1,286 & 147 & 28 & 175 & 17 & 7 \\
\hline 11 & Badakhshan & 3,372 & 1,283 & 4,655 & 1,250 & 2,044 & 3,294 & 73 & 1 \\
\hline 12 & Takhar & 2,435 & 560 & 2,995 & 1,043 & 149 & 1,192 & 32 & 3 \\
\hline 13 & Baghlan & 3,060 & 726 & 3,786 & 920 & 461 & 1,381 & 49 & 3 \\
\hline 14 & Kunduz & 1,429 & 288 & 1,717 & 855 & 792 & 1,647 & 25 & 1 \\
\hline 15 & Samangan & 336 & 106 & 442 & 132 & 34 & 166 & 9 & 3 \\
\hline 16 & Balkh & 3,442 & 2,068 & 5,510 & 702 & 1,486 & 2,188 & 42 & 3 \\
\hline 17 & Jawzjan & 6,621 & 4,458 & 11,079 & 501 & 941 & 1,442 & 40 & 8 \\
\hline 18 & Faryab & 1,011 & 520 & 1,531 & 174 & 145 & 319 & 11 & 5 \\
\hline 19 & Badghis & 396 & 32 & 428 & 101 & 69 & 170 & 8 & 3 \\
\hline 20 & Herat & 4,793 & 2,855 & 7,648 & 1,041 & 462 & 1,503 & 47 & 5 \\
\hline 21 & Farah & 479 & 42 & 521 & 227 & 46 & 273 & 18 & 2 \\
\hline 22 & Nimroz & 127 & 49 & 176 & 79 & 246 & 325 & 5 & 1 \\
\hline 23 & Helmand & 698 & 61 & 759 & 306 & 266 & 572 & 27 & 1 \\
\hline 24 & Kandahar & 342 & - & 342 & 645 & 134 & 779 & 37 & 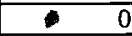 \\
\hline 25 & Zabul & 105 & - & 105 & 128 & 13 & 141 & 12 & 1 \\
\hline 26 & Uruzgan & 72 & - & 72 & 123 & - & 123 & 6 & 1 \\
\hline 27 & Ghor & 1,359 & - & 1,359 & 195 & 7 & 202 & 24 & 7 \\
\hline 28 & Bamyan & 366 & 170 & 536 & 564 & 43 & 607 & 20 & 1 \\
\hline 29 & Paktika & 86 & . - & 86 & 124 & - & 124 & 4 & 1 \\
\hline 30 & Saripul & 145 & 51 & 196 & 101 & 73 & 174 & 10 & 1 \\
\hline 31 & Khost & 1,265 & - & 1,265 & 57 & - & 57 & 18 & 22 \\
\hline 32 & Nooristan & 1,206 & - & 1,206 & 31 & - & 31 & 9 & 39 \\
\hline & Kabul City & 20,706 & 16,078 & 36,784 & 2,393 & 1,698 & 4,091 & 79 & 9 \\
\hline Total o & of Provinces & 61,766 & 15,140 & 76,906 & 13,232 & 8,013 & 21,245 & 859 & 4 \\
\hline Grand & Total & 82,472 & 31,218 & 113,690 & 15,625 & 9,711 & 25,336 & 938 & 4 \\
\hline
\end{tabular}




\section{Annex B: MoE Teacher Training Plan}

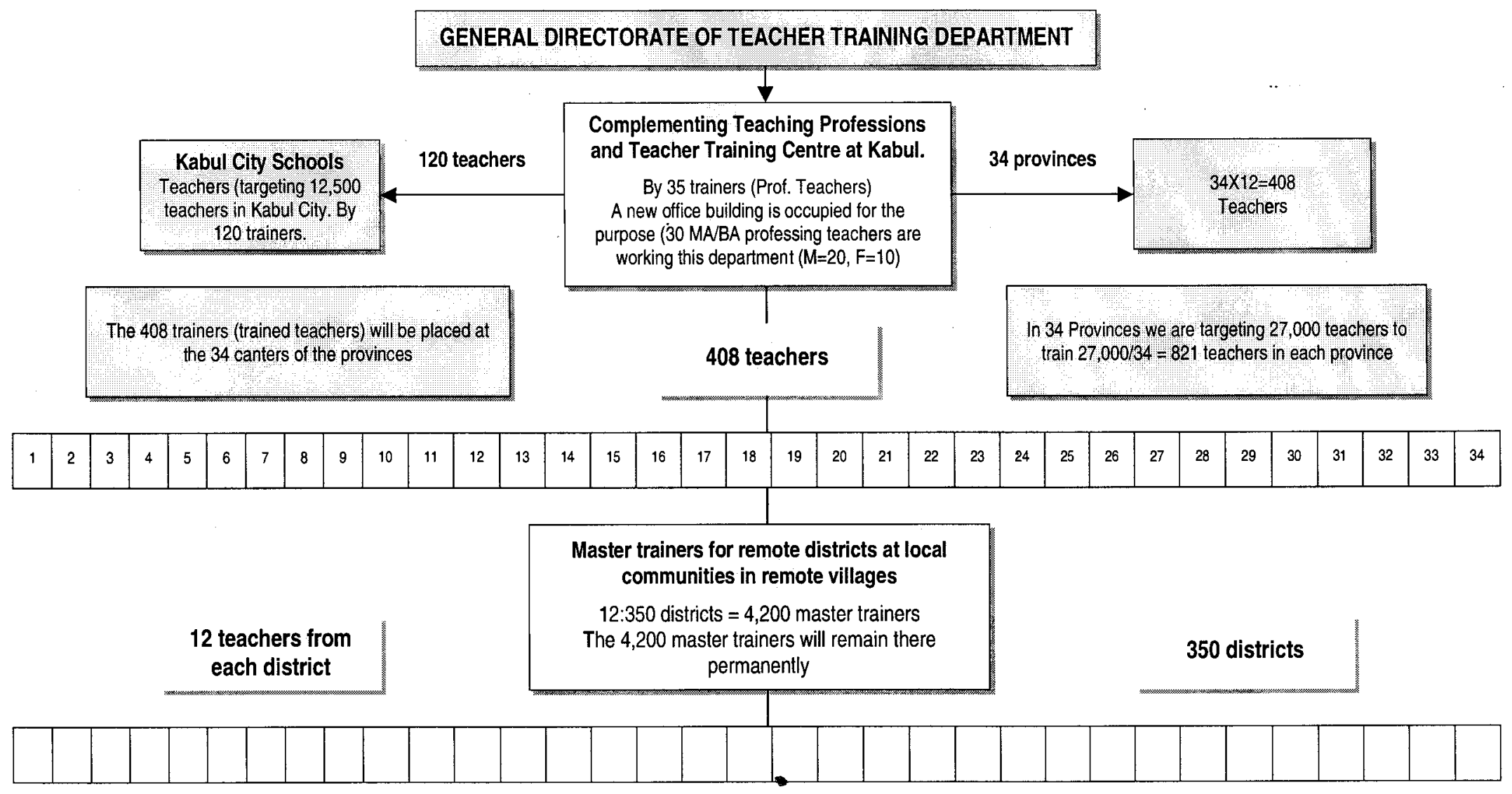

Note: $1 . \quad$ In each province 12 teachers will organise a base for the teacher training programmes

2. In a far remote area of the district country-wide, all the school teachers will be trained by the Master Trainers

3. All the Master Trainers of the provinces and districts (12 in each) will remain in their centres permanently

Source: Teacher Training Department MoE 2004 


\section{Annex C: World Bank Project Outline}

\begin{tabular}{|c|c|c|c|}
\hline \multicolumn{3}{|c|}{ Subcomponent } & \multirow[t]{2}{*}{ Implementation Steps } \\
\hline \multicolumn{3}{|c|}{ Component 1: School Grants (USS21 million) } & \\
\hline & $\begin{array}{l}\text { School Grants for } \\
\text { Quality } \\
\text { Enhancement } \\
\text { (Quality Grant) } \\
\text { (US\$10 miflion) }\end{array}$ & $\begin{array}{l}\text { To encourage school-based } \\
\text { decision making and resource } \\
\text { management through Parent } \\
\text { Teacher Associations } \\
\text { (PTAs)/School Management } \\
\text { Committees (SMCs) and active } \\
\text { community participation }\end{array}$ & $\begin{array}{l}\text { (1) PTAs/SMCs envision 'effective' schools, assess the current } \\
\text { situation, and prepare a school development plan; (2) PEDs } \\
\text { appraise and approve the school development plan; (3) MoE, } \\
\text { through PEDs, or NGOs provides block grants to schools, and } \\
\text { schools to contribute } 10 \% \text { of the grant in cash, labor, or kind; (4) } \\
\text { PTAs/SMCs implement the plan; communities, teachers, DEDs } \\
\text { monitor the progress; and (5) Additional funding would be made } \\
\text { available for the following years upon completion of the successful } \\
\text { implementation in the first year. }\end{array}$ \\
\hline & $\begin{array}{l}\text { School Grants for } \\
\text { Infrastructure } \\
\text { Development } \\
\text { (Infrastructure Grant) } \\
\text { (USD\$11 million) }\end{array}$ & $\begin{array}{l}\text { To rehabilitate and construct } \\
\text { schools using upgraded local } \\
\text { technology and community } \\
\text { participation }\end{array}$ & $\begin{array}{l}\text { (1) Department of Construction, MoE develops a menu of design } \\
\text { and technology options; (2) DEDs and PEDs prepare a list based } \\
\text { on the criteria; (3) Eligible schools prepare an infrastructure } \\
\text { development plan; (4) PEDs or NGOs provide block grants to } \\
\text { schools, and schools contribute } 10 \% \text { in cash, labor or kind; (5) } \\
\text { Schools manage the construction with help from PEDs and/or } \\
\text { NGOs; and (6) Schools prepare a maintenance plan. }\end{array}$ \\
\hline \multicolumn{4}{|c|}{ Component 2. Support to Schools through Human Resource Developmeni (USS11 5 million) } \\
\hline & $\begin{array}{l}\text { Teacher Training } \\
\text { (US\$7 million) }\end{array}$ & $\begin{array}{l}\text { To improve the subject content } \\
\text { knowledge and pedagogical skills } \\
\text { of teachers (and certify untrained } \\
\text { teachers) by implementing a } \\
\text { national competency-based } \\
\text { teacher development framework. } \\
\text { To support multi-stakeholder } \\
\text { programme on teacher education }\end{array}$ & $\begin{array}{l}\text { (1) MOE with help from experts develops teaching standards; (2) } \\
\text { MoE develops a common teacher education curriculum with local } \\
\text { adaptability; (3) MoE develops a national in-service training system } \\
\text { and program, and competency-based teacher certification } \\
\text { modules; (4) MoE with various partners (NGOs, University of } \\
\text { Education, etc.) implements in-service teacher training activities, } \\
\text { by bringing teacher training closer to schools and using mobile } \\
\text { teams, teacher resource room attached to schools, etc. }\end{array}$ \\
\hline 2.2 & $\begin{array}{l}\text { Development of } \\
\text { School Principals } \\
\text { (US } \$ 1.5 \text { mitlion) }\end{array}$ & $\begin{array}{l}\text { To enhance the capacity of } \\
\text { school principals as } \\
\text { administrators/managers and } \\
\text { instructional leaders }\end{array}$ & $\begin{array}{l}\text { (1) Define and enhance the responsibility and accountability of } \\
\text { school principals; (2) Develop selection criteria and training } \\
\text { modules; (3) Develop training programmes for school principals as } \\
\text { administrators/managers and instructional leaders; (4) Train } \\
\text { master trainers and/or contract out to NGO trainers; (5) Provide } \\
\text { training at Province and District level plus cross fertilization through } \\
\text { school principals workshops, etc. }\end{array}$ \\
\hline & $\begin{array}{l}\text { Capacity Building of } \\
\text { District and } \\
\text { Provincial } \\
\text { Education } \\
\text { Departments } \\
\text { (US\$3 million) }\end{array}$ & $\begin{array}{l}\text { To streamline the functions of } \\
\text { PEDs and DEDs and enhance } \\
\text { their capacities to do the job } \\
\text { effectively }\end{array}$ & $\begin{array}{l}\text { (1) Review of the current function and institutional capacity of } \\
\text { PEDs and DEDs; (2) Define and enhance the responsibility and } \\
\text { accountability structure of PEDs and DEDs; (3) Develop training } \\
\text { modules and system for key functions; (4) Train master trainers } \\
\text { and/or contract out to NGO trainers; (5) Carry out training at } \\
\text { Province and District level with cross fertilization through study } \\
\text { visits to other provinces; and (6) Provide institutional development } \\
\text { grants to PEDs and DEDs. Grant amounts would be decided using } \\
\text { a formula with both fixed and per capita components. }\end{array}$ \\
\hline \multicolumn{4}{|c|}{ Component 3. Policy Development and MaE (USS $2.5 \mathrm{millon})$. } \\
\hline 3.1 & $\begin{array}{l}\text { Policy Development } \\
\text { (US \$ } 1 \text { million) }\end{array}$ & $\begin{array}{l}\text { To strengthen the linkage } \\
\text { between budget preparation, } \\
\text { program implementation and } \\
\text { policy development } \\
\text { To build the capacity of the MoE } \\
\text { for effective policy making }\end{array}$ & $\begin{array}{l}\text { (1) Continue key technical assistance from the ongoing project to } \\
\text { help MoE implement a medium-term policy framework and } \\
\text { institutional development plan, and prepare a sound National } \\
\text { Development Budget each year; (2) Each, MoE decides and } \\
\text { undertakes policy-relevant topics and undertakes operational } \\
\text { research that would feed into the decision making for policy } \\
\text { formulation; and (3) Annually, collect data from schools and use } \\
\text { making use data for planning and decision making. }\end{array}$ \\
\hline & $\begin{array}{l}\text { Monitoring \& } \\
\text { Evaluation }\end{array}$ & $\begin{array}{l}\text { To establish and implement a } \\
\text { practical monitoring and } \\
\text { evaluation system for EQUIP and } \\
\text { MoE to draw lessons in a timely } \\
\text { fashion and feed into policy } \\
\text { making. To assess the status of } \\
\text { teachers (attendance and } \\
\text { qualifications) and funds flow. } \\
\text { To pilot assessment of student } \\
\text { learning outcome. }\end{array}$ & $\begin{array}{l}\text { (1) Undertake a baseline survey and follow-up surveys of } \\
\text { programme implementation at the end of year two; (2) Undertake } \\
\text { annual surveys to monitor the cost, impact, and implementation of } \\
\text { the school-based funding scheme, plus annual updating of the } \\
\text { school mapping database and evaluation of construction progress; } \\
\text { (3) Carry out teacher verification (attendance, qualifications skills) } \\
\text { and assessment of fund flow including salaries; and (4) Introduce } \\
\text { appropriate student assessment through pilot activities. }\end{array}$ \\
\hline
\end{tabular}




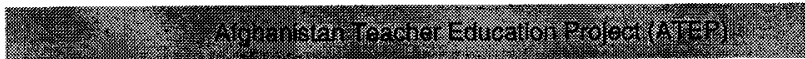

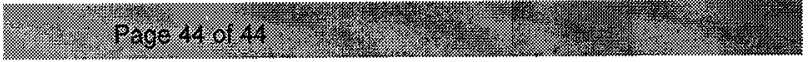

